\title{
Mesoporous Silica Nanoparticles: Properties and Strategies for Enhancing Clinical Effect
}

\author{
Alex N. Frickenstein 1,2 ${ }^{\circledR}$, Jordan M. Hagood ${ }^{2}$, Collin N. Britten ${ }^{3}$, Brandon S. Abbott ${ }^{3}{ }^{(}$, Molly W. McNally ${ }^{2}$, \\ Catherine A. Vopat ${ }^{1}$, Eian G. Patterson ${ }^{4} \oplus$, William M. MacCuaig ${ }^{1,2}$, Ajay Jain ${ }^{5}$, Keisha B. Walters ${ }^{3}\left({ }^{1}\right.$ and \\ Lacey R. McNally $2,5, *$
}

1 Stephenson School of Biomedical Engineering, University of Oklahoma, Norman, OK 73019, USA; africk256@ou.edu (A.N.F.); Catherine.A.Vopat-1@ou.edu (C.A.V.); wmaccuaig@ou.edu (W.M.M.)

2 Stephenson Cancer Center, University of Oklahoma, Oklahoma City, OK 73104, USA; Jordan-Hagood@ouhsc.edu (J.M.H.); molly-mcnally@ouhsc.edu (M.W.M.)

3 School of Chemical, Biological, and Materials Engineering, University of Oklahoma, Norman, OK 73019, USA; collin.britten@ou.edu (C.N.B.); brandonabbott@ou.edu (B.S.A.); keisha.walters@ou.edu (K.B.W.)

4 Department of Biology, University of Oklahoma, Norman, OK 73019, USA; eian_pat@ou.edu

5 Department of Surgery, University of Oklahoma, Oklahoma City, OK 73104, USA; Ajay-Jain@ouhsc.edu

* Correspondence: lacey-mcnally@ouhsc.edu; Tel.: +1-(405)-271-8001

check for updates

Citation: Frickenstein, A.N.; Hagood, J.M.; Britten, C.N.; Abbott, B.S.; McNally, M.W.; Vopat, C.A.; Patterson, E.G.; MacCuaig, W.M.; Jain, A.; Walters, K.B.; et al. Mesoporous Silica Nanoparticles: Properties and Strategies for Enhancing Clinical Effect. Pharmaceutics 2021, 13, 570. https://doi.org/10.3390/ pharmaceutics 13040570

Academic Editors: Kytai T. Nguyen, Jyothi U. Menon and G. Van den Mooter

Received: 8 February 2021

Accepted: 7 April 2021

Published: 17 April 2021

Publisher's Note: MDPI stays neutral with regard to jurisdictional claims in published maps and institutional affiliations.

Copyright: (c) 2021 by the authors. Licensee MDPI, Basel, Switzerland. This article is an open access article distributed under the terms and conditions of the Creative Commons Attribution (CC BY) license (https:// creativecommons.org/licenses/by/ $4.0 /)$.

\begin{abstract}
Due to the theragnostic potential of mesoporous silica nanoparticles (MSNs), these were extensively investigated as a novel approach to improve clinical outcomes. Boasting an impressive array of formulations and modifications, MSNs demonstrate significant in vivo efficacy when used to identify or treat myriad malignant diseases in preclinical models. As MSNs continue transitioning into clinical trials, a thorough understanding of the characteristics of effective MSNs is necessary. This review highlights recent discoveries and advances in MSN understanding and technology. Specific focus is given to cancer theragnostic approaches using MSNs. Characteristics of MSNs such as size, shape, and surface properties are discussed in relation to effective nanomedicine practice and projected clinical efficacy. Additionally, tumor-targeting options used with MSNs are presented with extensive discussion on active-targeting molecules. Methods for decreasing MSN toxicity, improving site-specific delivery, and controlling release of loaded molecules are further explained. Challenges facing the field and translation to clinical environments are presented alongside potential avenues for continuing investigations.
\end{abstract}

Keywords: mesoporous silica; theranostics; theragnostics; nanomedicine; cancer; active targeting; toxicity; controlled release

\section{Introduction}

Small molecule approaches to diagnostic and therapeutic procedures suffer from multiple shortcomings, such as off-target toxicity and rapid clearance from the body. Boasting the ability to simultaneously diagnose and treat patients, theragnostic (a.k.a. theranostic) nanoparticles (NPs) emerged as a rapidly developing technology for overcoming these obstacles and enhancing clinical outcomes. In particular, mesoporous silica nanoparticles (MSNs) demonstrate a significant potential [1] to become a standard part of the therapeutic armamentarium for various diseases. MSNs possess sufficient biocompatibility, particularly compared to other inorganic NPs, alongside highly structured and stable porous networks, into which drug or dye molecules can be loaded in large quantities. Additionally, the size, shape, and pore properties of MSNs can be highly controlled during synthesis reactions [2], providing multiple NP formulations from the same composite elements.

Pairing with appropriate gatekeeper molecules can trap encapsulated molecules within the MSN pores, allowing for efficacious cargo release. In addition, the gatekeeper provides surface functionalization to prevent toxicity. These gatekeeper mechanisms 
protect the nontarget tissues - in the host environment-from loaded molecules, while simultaneously protecting the loaded molecules from the environment. This two-way shielding provided by MSNs allows for in vivo delivery of small molecules that, alone, would be clinically ineffective as a result of their high hydrophobicity or toxicity [3].

The multifunctional nature of MSNs largely stems from the numerous surface modifications they can undergo. As mentioned, many different gatekeeper molecules can be employed to the encapsulated molecules loaded into MSN pores. These gatekeeper molecules can be chosen or designed to respond to disease-specific stimuli, thus, controlling the release of loaded molecules and limiting off-target delivery [4]. The organic nature of gatekeeper molecules also serves to limit immunogenic responses from the host that might otherwise occur. If unmodified MSNs were administered with or without gatekeepers, MSN surfaces could be effectively modified to specifically target them to selected tissues or sites of disease. This feature differentiates MSNs from NP formulations that might rely solely on passive targeting mechanisms to reach their target destination. The number of possible active targeting molecules is vast and ever growing, further promoting the application of MSNs in identifying and treating many different diseases.

Compared to the number of preclinical studies, very few silica-based nanomedicine approaches were FDA approved for clinical trials [5,6]. Continued investigation of MSN formulations is contingent upon understanding the myriad factors influencing MSN clinical efficacy. As MSN technology advances, characteristics of MSNs and their correlating structural modifications to function, specificity, and toxicity needs to be well understood. This review highlights recent advances with MSNs relative to cancer theragnostics. MSN properties (see Figure 1) that promote clinical efficacy are detailed with a particular focus on surface properties and toxicity. Targeting strategies employed by MSNs are similarly discussed, highlighting the advantages and options for active targeting methods. Theragnostic actions of MSNs are discussed as well, in addition to the many clinical applications and strategies to reduce the potential toxicities from the MSNs. Finally, future directions for the field are briefly analyzed, relative to enhancing clinical translation.

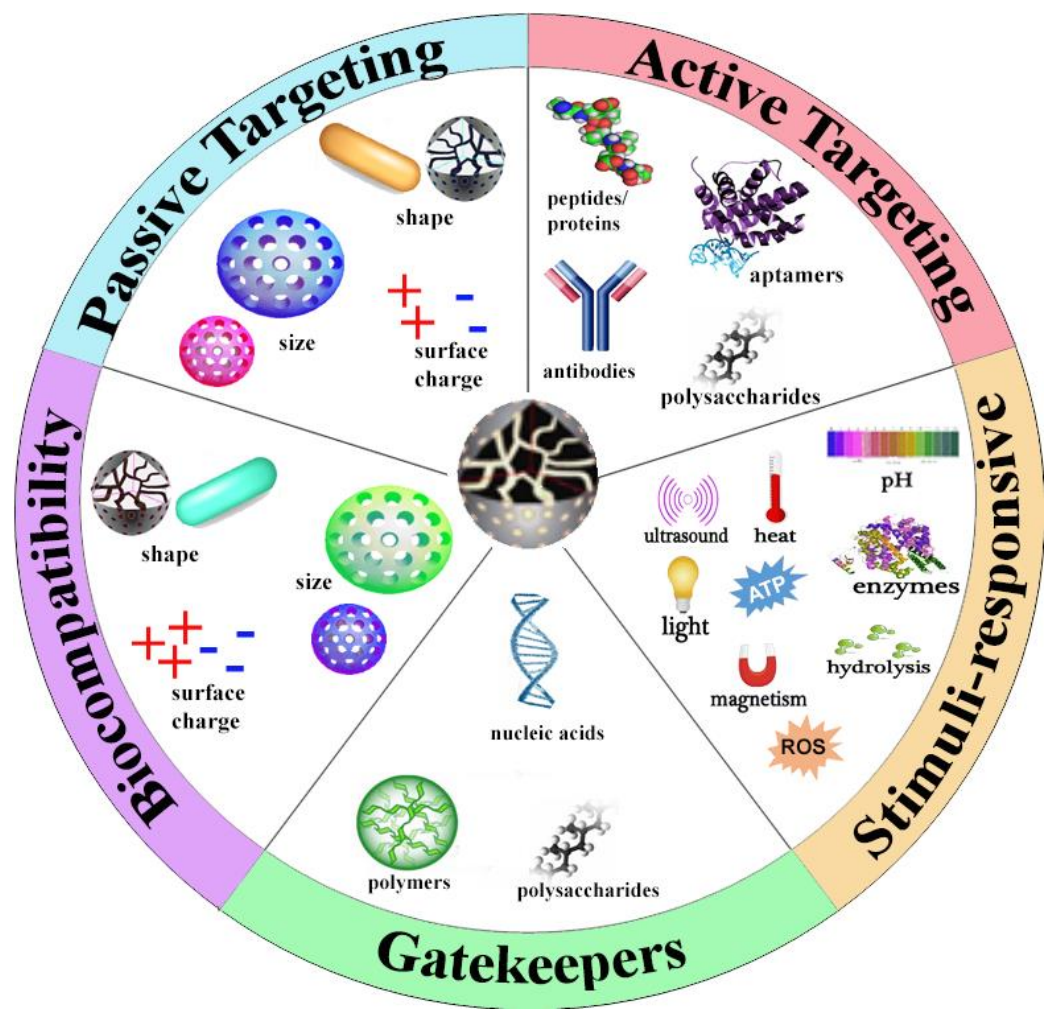

Figure 1. Characteristics of MSNs that drive theragnostic effect. 


\section{Characteristics of MSNs}

While many reaction pathways might be used [7,8], MSNs are primarily synthesized through sol-gel reactions [9-12]. Surfactant molecules, such as hexadecyltrimethylammonium bromide (CTAB), are dissolved in ultrapure water, prior to addition of cosolvents and tetralkoxy silicate precursor molecules. The most commonly used silicate precursor used in MSN synthesis is tetraethyl orthosilicate (TEOS). Tetrapropyl orthosilicate (TPOS) and tetramethyl orthosilicate (TMOS) are alternative options used in some studies, though TEOS is favored, given the apparent ease to control TEOS reaction output $[7,13]$. Selection of surfactant molecule, cosolvents (typically alcohols or strong bases), reaction temperature, and magnetic stir speed, all determine the size, shape, and porosity of the synthesized MSN product. Investigations into the relation between silicate precursor and particle size are ongoing. Following synthesis of MSN core particles, template surfactant molecules, such as the commonly used $\mathrm{CTAB}$, must be removed to maximize effective pore volmers. Additionally, surfactant molecules can be toxic in vivo, as is the case with CTAB [14-17], requiring their removal from MSN pores, prior to clinical applications. Several methods for surfactant removal might be applied, including washing with water and ethanol, dialysis [18], or calcination [19]. Surfactant removal might be followed by additional steps that modify core MSN functional groups, conjugate a gatekeeper system to the MSN surface, or conjugate active targeting ligands to the MSN nanovehicle. Figure 2 provides an overview of the functionalization and theragnostic action of MSNs.

A<smiles>CCCO[Si](OCCC)(OCCC)OCCC</smiles>

B

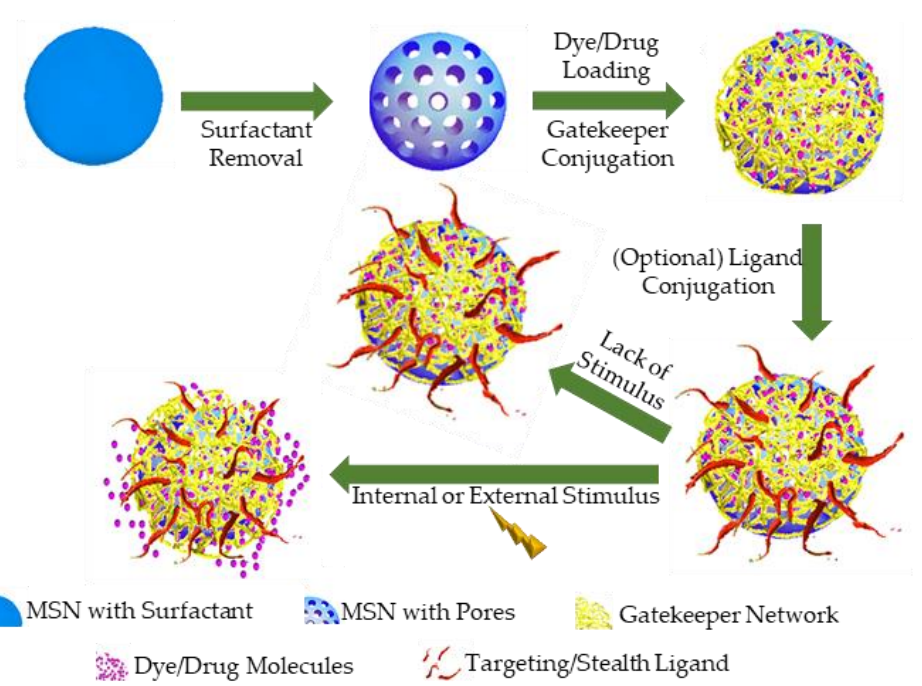

Figure 2. MSN precursors and theragnostic action. (A) The common orthosilicate precursors used in MSN synthesis reactions. (B) MSN synthesis, loading, and controlled release. Note that the surface of the MSN is coated with a biocompatible gatekeeper. The biocompatible gatekeeper has a dual role in that it allows retention or release of dye/drug molecules and facilitates biocompatibility of the nanoparticle to reduce toxicity. A stimulus can result in swelling or destruction of a stimuliresponsive gatekeeper. A dye/drug can release based upon stimuli-responsive changes in the gatekeeper, regardless of the presence/absence of an active targeting molecule by diffusion. 
Strategically tailoring MSN surface-oriented functional groups provides avenues to better control interfacial interactions, while offering additional functionality like drug loading and insertion of targeting domains. Both chemical treatment and polymer grafting strategies are widely used approaches for chemically or morphologically modifying MSN surfaces $[20,21]$. Self-assembled monolayers (SAMs), such as silanes on hydroxylated surfaces, offer one facile and flexible approach at introducing a wide array of functional groups to MSN surfaces. Comprising a head group, a hydrocarbon-based backbone, and a functional end group, silane-based SAMs spontaneously adsorb onto the hydroxylated surface of MSNs. Afterwards, SAMs self-organize to form larger structured domains (i.e., ca. 1-3 nm organic thin films) and become well-ordered through van der Waals interactions. The result provides close-packed terminal groups that can be used as initiation sites for grafting polymeric material [22]. Through the initiation of the surface-oriented SAM functional groups, polymers exhibiting a plethora of confirmations and arrangements can be surface-confined (i.e., grafted). Tailoring the grafting and polymerization approach allows for the synthesis of reproducible, well-defined, polymeric brushes with tunable macromolecular properties that enhance the MSN theragnostic potential.

Beyond the impact of polymeric, gatekeeper, or active targeting molecules, innate properties of the core MSN serve as key predictors of physiological fate. Prior to administration, complete characterization of MSNs is critical to approximating MSN behavior and correlating the theragnostic effect. Some of the common methods for verifying MSN properties by analyzing synthesized particles are dynamic light scattering (DLS) [23] and transmission electron microscopy (TEM); and by analyzing the specific surface area calculations through the Brunauer-Emmett-Teller (BET) methods [24]. Understanding how the tunable traits of MSNs influence potential theragnostic action is critical to optimizing clinical efficacy.

\subsection{Size}

Several organ systems within the body possess structural or functional filtration abilities. For example, the glomerular layers of the kidney are responsible for filtering foreign and waste products that are smaller than approximately $5 \mathrm{~nm}[25,26]$. Simultaneously, the highly vascularized liver and spleen uptake particulates of $100 \mathrm{~nm}$ from the bloodstream for removal via the reticuloendothelial system (RES), through Kupffer cells or splenic macrophages, respectively [27-31]. Given these risks of RES clearance and excessive renal filtration, it is important to synthesize particles that are of appropriate size for maximum retention time and clinical efficacy. NPs within the size range of 20-80 nm appear to be most favorable for avoiding the various physiological "traps" in the body, while promoting target site accumulation [32-34]. Size-based studies of MSNs demonstrate the increased ability of MSNs within this size range to reach target sites relative to larger MSNs [35-37]. Based on these size restrictions, MSNs synthesized from TEOS might be less effective for in vivo application, depending on the synthesis method employed. MSNs comprised of TMOS suffer the disadvantage of an increased tendency to aggregate after synthesis $[7,10]$, but this issue is largely overshadowed by their smaller size of $\sim 30 \mathrm{~nm}$, prior to modification [38].

While control of the MSN size is primarily accomplished prior to treatment, it is critical to consider the fact that significant changes in the nanovehicle size might occur from physiological reactions in vivo. Following intravenous administration, MSNs are exposed to numerous proteins in the blood. Under certain conditions, these proteins can irreversibly bind the MSN surface through a process termed as opsonization [39,40]. The resulting protein corona, with the NP in the center, has an increased effective size relative to the original MSN. This can result in increased splenic or liver sequestration and clearance. Opsonization might decrease the likelihood that the MSNs would be immediately recognized as foreign material and subsequently trigger an immunological response [41]. This could result in increased MSN circulation time, although the interaction with target cells is hampered by the large proteins bound to the nanovehicle surface. The magnitude and variety of protein content in the corona was found to vary significantly, based on 
MSN size and surface functionalization [42-44]. Additionally, endogenous biomolecules exposed to or existing as part of the protein corona might undergo structural and functional alterations [45]. Such alterations might activate undesired signaling pathways or immune cells, ultimately leading to immunogenic or toxic side effects [46-48]. Protection against opsonization could be achieved by conjugating organic polymers or biomolecules (such as gatekeepers or targeting ligands) to the surfaces of MSNs [49-51].

\subsection{Shape and Porosity}

The final shape of the MSN core plays a similarly critical role in physiological fate and in vivo MSN behavior. MSNs are most commonly shaped as spheres or rods. The final shape primarily depends on the identity and volume ratio relative to water, in the cosolvent used during the sol-gel reaction [52]. The aspect ratio (AR) of synthesized rod MSNs is similarly dependent on reaction conditions, namely temperature and magnetic stir speed. MSN shape and aspect ratio significantly affect in vivo circulation time and tissue penetration. In general, it was observed that rod shaped MSNs of sufficient AR (approximately 2.1-2.5) exhibit higher blood circulation times and tumor penetration depths, as compared to spherical MSNs or rods of different AR values (see Figure 3D) [34,53-55]. Rate of engulfment by target cells is also influenced by MSN shape and AR, though the results might be cell-line dependent [56]. Other MSN morphologies were also explored [57]. For example, MSNs possessing rough surfaces, demonstrated increased uptake by target cells, as compared to both solid and mesoporous silica counterparts. These unique virus-like MSNs were generated through additional synthesis steps, following the initial MSN core formation $[58,59]$.
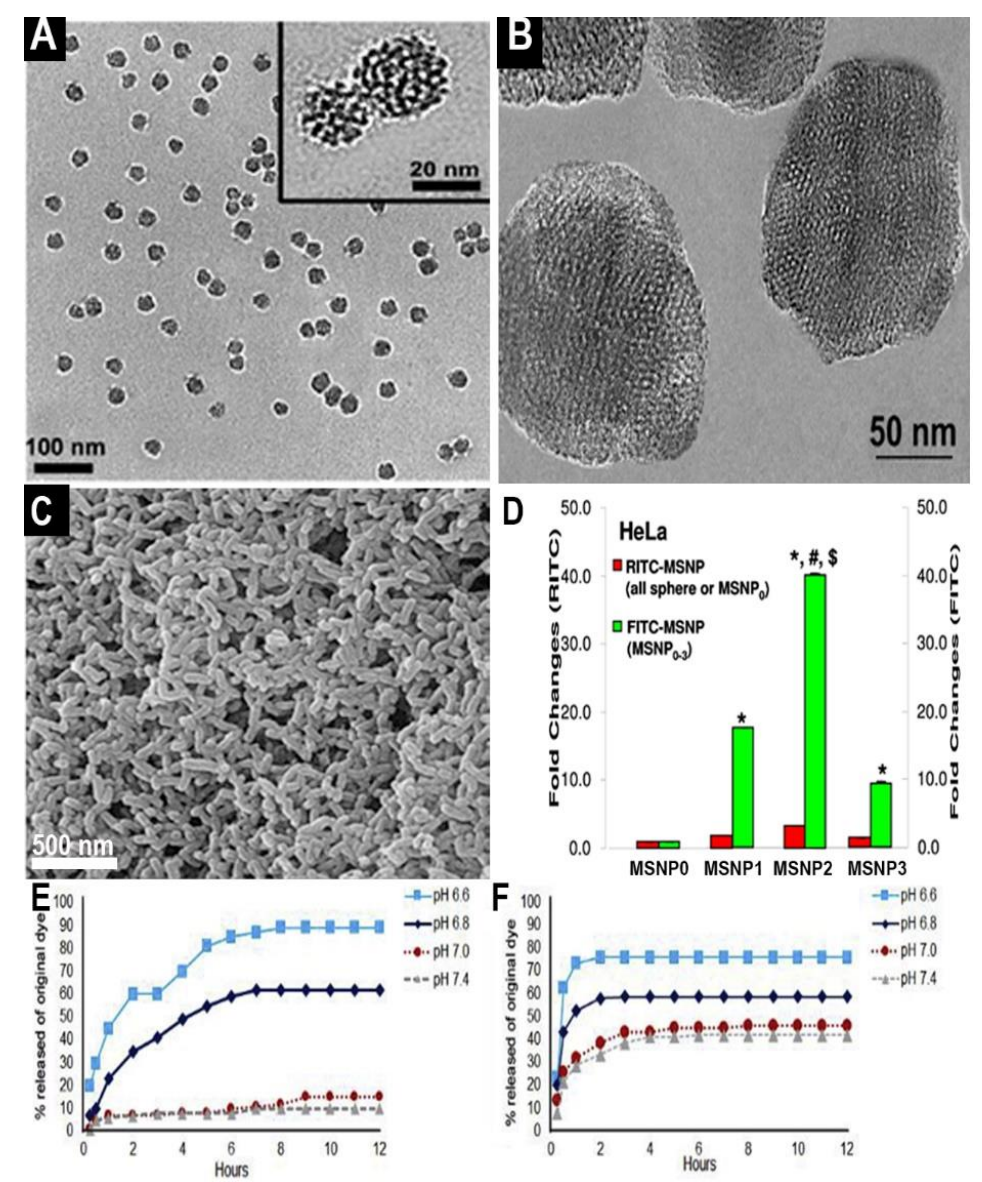

Figure 3. Shape and porosity differences between MSNs influence outcomes. (A) Wormhole pore 
MSNs with a particle diameter of $25 \mathrm{~nm}$ and a pore diameter of $1.3 \mathrm{~nm}$, reprinted with permission from [38], Elsevier, 2018. (B) Honeycomb pore MSNs with a particle diameter of $130 \mathrm{~nm}$. (C) Rodshaped MSNs synthesized from TEOS, reprinted with permission from [60], Elsevier, 2020. (D) MSN rods of $\mathrm{AR} \approx 2.1-2.5$ (MSNP2) exhibited high uptake in HeLa cells, according to the RITC and FITC analysis, as compared to spheres (MSNP0) and rods of smaller (MSNP1) and larger (MSNP3) AR values; * indicates $p<0 . .05$ when compared with MSNP0; \# indicates $p<0.05$ when compared with MSNP1; \$ indicates $p<0.05$ when compared with MSNP3. Reprinted with permission from [53], ACS Publications, 2011. (E) Wormhole porous MSNs with chitosan gatekeeper networks exhibit more favorable $\mathrm{pH}$-specific controlled release compared to $(\mathbf{F})$ honeycomb porous MSNs with the same gatekeeper. (A,B,E,F) reprinted with permission from [38], Elsevier, 2018.

MSN porosity is characterized by the shape, diameter, and number of pores. Pore shape is primarily determined by the cosolvents used during synthesis. The standard honeycomb pore shape is produced when strong bases such as $\mathrm{NaOH}$ are used for the cosolvent [61,62]. Wormhole pores are generated when other cosolvents like triethylanolamine (TEA) are included in the synthesis reaction [38,63]. Honeycomb MSNs exhibit less restricted pore spaces and more stable colloidal suspensions than those with wormhole pores. The release of honeycomb loaded molecules, however, occurs in a less controlled fashion (resembling burst-release kinetics), as compared to the wormhole loaded agents (see Figure 3E-F) [38]. After MSN synthesis, pore size could be decreased by up to $\sim 0.5$ nm via vacuum-assisted vapor deposition of TEOS or TMOS [64,65]. Such adjustment of pore size permits finer control over the loaded molecule release rates and the functional surface area of the MSN core. While this increase in surface area might promote MSN-cell interactions, it also provides additional sites for MSNs to interact with healthy host cells, increasing the risk of toxic effects or off-target accumulation [66].

\subsection{Surface Properties, Charge, and Toxicity}

The major function of MSNs is the specific delivery of encapsulated cargo to a target location in vivo. To incorporate specificity, often a stimuli-sensitive gatekeeper is added to the surface of the MSNs. In addition to providing stimuli-responsivity for cargo release, the gatekeeper has the capability to circumvent toxicity. As the major benefit of the mesoporous nature of the MSNs allows for release of a cargo in conjunction with a particular disease, the MSN should have a gatekeeper on the surface of the MSN to allow promotion of sitespecific drug/dye release. While non-coated MSNs reportedly induced proinflammatory and toxic responses, notably through accumulation in the liver and kidney [67,68], noncoated MSNs do not have cargo release specificity, hindering clinical application. Addition of gatekeeper molecules to the surface of MSNs provides the specificity for cargo release, while simultaneously ameliorating toxicity concerns.

The primary functional group present on unmodified MSNs is silanol, which has the general form $\equiv \mathrm{Si}-\mathrm{OH}[69]$. The silica atom is bound to at least one oxygen atom, which could be protonated or deprotonated, depending on the environmental $\mathrm{pH}$ or could bind to other neighboring silica atoms [70]. The other groups bound to silica atoms are dependent on the orthosilicate molecule used to synthesize the MSN (see Figure 2A for common examples) and the reaction conditions applied. For example, the silanol group can exist in an isolated $\equiv \mathrm{Si}-\mathrm{OH}$ form, a germinal $=\mathrm{Si}-(\mathrm{OH})_{2}$ form, or as a series of siloxanes (e.g., $\equiv$ Si-O-Si-O-Si $\equiv$ ). Additionally, hydrogen bonds can form between silanols, based on group density, forming vicinal silanol groups [70,71]. At physiological $\mathrm{pH}$ values of 7.4, hydrogen-containing silanol groups can become deprotonated, resulting in a net negative charge for MSN surfaces [72]. NPs with negative charges are less likely overall to interact with or be engulfed by nonphagocytic cells, thus, prolonging the NP circulation time [73,74]. This benefit of the negative charge comes at the cost of increased risk for hemolytic interactions between MSNs and red blood cells, based on the MSN negative charge $[66,75,76]$. The negative charges also interact unfavorably with the immune cells and functions. For example, negatively charged MSNs are shown to inhibit growth and 
multiplication of lymphocytes $[77,78]$. The negative charge might increase the rate of opsonization as well [79]. Unsurprisingly, MSN shape, size, porosity, and dose concentration influence the magnitude of these toxic effects, based on the number of negatively charged silanol groups available for interaction.

Functional group modification is assessed as a method for altering MSN cellular interactions. For example, silanol groups can be replaced with the amine functional groups for the net positive surface charge [80]. MSNs possessing amine or carboxyl surface functional groups demonstrated significantly lower immune cells cytotoxicity, as compared to the unmodified MSNs [81]. Similarly, MSNs grafted with phosphonate groups show enhanced drug delivery to tumor cells with limited undesirable cytotoxicity or opsonization [35,76], despite having a negative charge. Amine- and phosphate-modified MSNs show similarly mitigated proinflammatory responses that can be induced by the unmodified MSNs and even MSNs conjugated with poly(ethylene glycol) (PEG) [67]. Relative to protecting blood lymphocytes from damage caused by unmodified MSNs, surface modifications using vinyl and aminopropyl/vinyl functional groups exhibited a limited cytotoxic effect [82]. While the discussed options focus on MSN surface groups in relation to toxicity, surface modification was also performed to enhance MSN encapsulation and delivery of molecular cargo [83].

Maintaining non-toxicity of MSNs is crucial in the pursuit of clinical adaptation. Thus far, MSN coatings focus on alternative uses for the biocompatible materials used in applications such as wound healing [84] or topical biostimulation methods [85]. Chitosan is a naturally occurring polysaccharide with $\mathrm{pH}$-responsivity and is widely regarded as a non-toxic coating for MSNs [86]. However, careful derivatization of chitosan is required to ensure no potential toxic contamination occurs, notably by surpassing injection concentration thresholds or due to reduction of the positive surface charge [87]. Hyaluronic acid (HA) is a glycosaminoglycan occurring in the extracellular matrix critical to cell growth and stability. HA was explored for topical and in vivo applications, ranging from skin rejuvenation to cancer therapy. Similar to chitosan, HA can be used in vivo without significant toxicity concerns, by adhering to the synthesis and conjugation guidelines [88]. Polydopamine and poly l-histidine are $\mathrm{pH}$-sensitive polymers that could be incorporated as an MSN coat to reduce the inflammatory responses. Each of these coatings, while providing stimuli-responsivity for cargo delivery, also exhibit no cytotoxicity or indications of fibrosis $[89,90]$. However, it is important to note that gatekeepers must be extensively investigated prior to use as MSN coating agents; biocompatible gatekeepers might induce undesired toxicity when conjugated to MSNs. For example, poly-ethylene glycol (PEG) is often described as a non-toxic stealth coating. PEGylated nanoparticles raise toxicity concerns, notably anaphylaxis [91], based on longer blood circulation times and limited cellular uptake [92]. While such described gatekeepers show a potential for biocompatibility as MSN coatings, varying applications might provoke undesired interactions, resulting in toxicity. Future investigations would require extensive evaluations of each MSN gatekeeper to ensure elimination of toxicity concerns. In addition to offering tailorable surface chemistries and limiting toxicity, graft polymerization stabilizes MSNs through electrostatic and steric effects, allows for the synthesis of a wide array of physical structures, and provides additional material functionality $[93,94]$. Macromolecules are grafted to MSN surfaces through two main approaches-grafting-to and grafting-from. Grafting-to strategies attach pre-formed polymers directly to MSNs, often utilizing click chemistry to attach a functionalized end group to the MSN surface $[95,96]$. However, grafting-to strategies are limited in polymer density, as the steric hindrance between polymer molecules increases the distance between individual chains [97]. This can result in a higher exposure of the bare MSN surface, increased risk of MSN toxicity, and decreased polymeric functionality. Grafting-from strategies, on the other hand, rely on attaching initiator moieties to MSNs and polymerizing directly from the MSN surface. This approach allows for higher grafting densities, as well as the tailoring of more complex polymer architectures, such as partial crosslinking to further increase surface density [97]. 
Often, polymer synthesis strategies rely on controlled radical polymerization (CRP) techniques, which allow for the controlled design of polymer architecture, chain length, branching, functionality, tacticity, stereochemistry, and composition, among other features. CRP strategies also retain functional end groups with high fidelity [98-102], allowing for design of block copolymers for multiple applications. Further, these end groups might be modified for conjugation to MSN surfaces or to active targeting moieties, to reduce off-target accumulation [103]. Commonly utilized CRP techniques include atom transfer radical polymerization (ATRP), reversible addition/fragmentation chain transfer polymerization (RAFT), and nitroxide-mediated polymerization (NMP). Due to the potential toxicity of the transition metal catalyst species needed for ATRP, RAFT polymerization received considerable attention as a more clinically suited method for controlled graft polymerization [104]. Lower toxicity catalyst systems for ATRP were recently assessed, including iron-mediated and even metal-free photo-ATRP $[105,106]$. Ultimately, CRP strategies allowed for the design of novel MSN-composites with tunable surface properties and interfacial interactions.

Besides altering the MSN surface chemistry, conjugation of organic molecules (such as polymers) to the surface of MSNs is a common strategy for limiting unfavorable MSNhost interactions. Conjugated molecules impart addition functions to MSN nanovehicles, including gatekeeping and active targeting. Some modifications are performed to protect the NP from the host, or vice versa. The most common example of such a molecule is PEG, whose biocompatibility was demonstrated in numerous NP formulations [107]. While PEG-modified MSNs show preclinical effectiveness with limited off-target toxicity and opsonization [108-112], they reach disease sites through passive targeting methods. This severely limits their efficacy and therapeutic potential in humans who benefit much more from the actively targeted MSNs. Additionally, PEG molecules can inhibit MSN interactions with target cells or limit long-term clinical effectiveness, as a result of the PEG-specific antibody formation [113-115].

Polymers, polysaccharides, and other organic-based molecules added to the surface of MSNs can substantially alter interactions between the host milieu and the NP, resulting in reduced toxicity. These surface coatings or gatekeeper molecules must exhibit significant biocompatibility and negligible toxicity. Specific assessment of toxicity for gatekeepers was performed for select molecules, including chitosan [87,116], poly(L-histidine) [117], polydopamine [89], and hyaluronic acid [118]. In each case, the molecules demonstrated limited toxicity for both in vitro and in vivo models. Continued toxicity assessment of current gatekeeper and surface functionalization molecules that show apparent preclinical effectiveness in MSN formulations is warranted. Future studies should further consider how MSN toxicity changes after surface modification and conjugation to targeting ligands.

\section{Molecular Encapsulation and Stimuli-Specific Release Response}

Given the porous nature of MSNs and the potential toxic effects associated with the exposed functional groups, additional chemical and structural mechanisms are needed to both encapsulate molecules loaded into MSN pores and to limit unfavorable interactions between the MSN surface and the host. These "gatekeeper" systems, commonly comprised of organic polymer networks, facilitate release of loaded molecules, once the MSNs reach the target location or cell. Additionally, they serve as a surface onto which other molecules, such as active targeting ligands, could be conjugated. A selection of polymeric gatekeeper molecules that demonstrated stimuli-specific response in preclinical studies are provided in Table 1.

Controlled release of encapsulated molecules is triggered by cell- or site-specific stimuli that changes the gatekeeper system, exposing the pores of the MSN. Any loaded molecules would then diffuse out of the MSN into the target environment. Appropriate selection of gatekeeper molecule requires knowledge of any internal stimuli produced in the target cell or environment that the gatekeeper would respond to. While common stimuli are found internally, external stimuli provided by clinicians might also be used 
after sufficient accumulation of MSNs at the target site. Given the extensive and evergrowing number of possible gatekeeper molecules, it is more valuable to consider the methods of triggering gatekeeper stimuli-specific response. Upon identifying the stimuli that matches the target disease, an appropriate gatekeeper can be used in formulating the MSN nanovehicle.

Table 1. Selection of MSN Gatekeepers.

\begin{tabular}{|c|c|c|}
\hline Molecule & Stimuli/Response & References \\
\hline Chitosan & $\begin{array}{c}\mathrm{pH} / \text { Protonation of primary amine results in swelling from like } \\
\text { charge repulsion }\end{array}$ & {$[38,61,62,119-121]$} \\
\hline Polyvinyl Pyridine & $\mathrm{pH} /$ Protonation from acidic environment induces hydrophilic behavior & {$[122,123]$} \\
\hline Poly(L-histidine) & $\mathrm{pH} /$ Amine group protonation results in degradation & {$[90,95]$} \\
\hline Poly(acrylic acid) & $\mathrm{pH} /$ Protonation results in shrinking of polymer chain & [124-126] \\
\hline Hyaluronic Acid & $\begin{array}{l}\text { Enzymes and GSH/Hyaluronidase breaks down HA polymeric } \\
\text { network or GSH breaks disulfide bond between HA and MSN }\end{array}$ & [127-131] \\
\hline Gelatin & $\begin{array}{l}\text { pH \& Enzymes/Protonation of amine groups results in network } \\
\text { swelling while MMPs degrade breakdown polymeric chains }\end{array}$ & {$[127,132-135]$} \\
\hline Polyglutamic Acid & Enzymes/Degraded through catalytic interaction with pronases & [136] \\
\hline Polydopamine & $\begin{array}{l}\mathrm{pH} \text { and Thermosensitivity/Acidity degrades polymer while high } \\
\text { energy from ultrasound or laser stimulation may induce unstable state }\end{array}$ & {$[112,137-140]$} \\
\hline Poly(N-isopropylacrylamide) & $\begin{array}{l}\text { Thermosensitivity/Temperatures above critical temperature result in } \\
\text { hypercoiled state of polymer, exposing MSN pores and surface }\end{array}$ & [141-144] \\
\hline
\end{tabular}

\subsection{Internal Stimuli}

3.1.1. $\mathrm{pH}$

The altered metabolic behavior of malignant cells results in the synthesis of acidic byproducts that are transported to the extracellular environment [145]. This phenomenon results in a decrease in extracellular $\mathrm{pH}$ from 7.4 (standard physiological $\mathrm{pH}$ ) to as low as 6.4 [146]. The lower extracellular $\mathrm{pH}$ in tumor tissues can be used as a strategy to facilitate targeted release of anti-cancer therapeutics agents from MSNs. Similarly, the acidic $\mathrm{pH}$ of endosomes and lysozymes into which MSNs are transported during endocytosis and degradation, respectively, is also used to trigger the release of encapsulated molecules [147]. The release results from the higher proton concentration, triggering a chemical shift in the selected gatekeeper molecules. For example, chitosan is a naturally occurring polymer that possesses a primary amine in its structure. At neutral pH values, the amine group is deprotonated, tightening the polymer network around the MSN. In acidic environments, the amine group is protonated, acquiring a positive charge and becoming highly hydrophilic [148]. This results in a swelling of the polymers around the pores [149], exposing pore contents to the environment and permitting diffusion of the encapsulated molecules out of the MSNs. While other functional or electrostatic groups might be used in gatekeeper molecules, the principle remains the same-acidic $\mathrm{pH}$ results in electrochemical changes that alter the gatekeeper network or interactions between the gatekeeper molecules and the MSN itself.

Chitosan is successfully used as a pH-sensitive gatekeeper in several MSN preclinical model studies [38,61,62,119-121]. Other polymers that demonstrate similar $\mathrm{pH}$ sensitivity include polyvinyl pyridine [122,123], poly(L-histidine) [90,95], poly(acrylic acid) [124-126], gelatin [132,133], and polydopamine [112,137-139]. Bonds between the gatekeeper molecules and the MSNs themselves could be chosen for their response to acidic $\mathrm{pH}$ as well, largely resulting in dissociation of gatekeeper molecules from the MSN surface. Examples of such formulations can utilize imine bonds [150-152], ester bonds [150,153,154], or hydrazine bonds [155], among others [147]. In all these cases, the gatekeeper molecule 
is organic in nature, improving biocompatibility between the MSN nanovehicle and the host while limiting toxicity. While organic $\mathrm{pH}$-gated molecules are commonly used, inorganic systems were studied as well. For example, latching mechanisms functionalized by metal ions of cobalt, nickel, or calcium show $\mathrm{pH}$-specific release of molecules loaded into MSNs [156]. Zinc quantum dots were similarly studied as MSN gatekeepers, given their rapid dissolution at acidic $\mathrm{pH}$ values $[157,158]$. One system showed similar biocompatibility and $\mathrm{pH}$-sensitive release, when using calcium carbonate-which dissociates into $\mathrm{Ca}^{2+}$ and $\mathrm{CO}_{3}{ }^{2-}$ ions in acidic $\mathrm{pH}[159]$.

\subsubsection{Enzymes}

While pH-response can preferentially increase delivery to preferred tissues, it is fundamentally a non-specific targeting strategy that can be neutralized by changes in $\mathrm{pH}$. Any change in the $\mathrm{pH}$ of the suspending solution would induce release of the loaded molecules. Gatekeeper motifs can be constructed to break down in the presence of more specific stimuli, such as enzymes. Malignant cells often overexpress enzymes that promote proliferative or metastatic behavior [160]. These enzymes can be found in either the extraor intracellular environment, providing additional avenues for gatekeeper application. Selection of gatekeeper molecules that are targeted for destruction by overexpressed or lysosomal enzymes promotes controlled release.

As with pH-sensitive gatekeepers, many molecular networks stimulated by enzymes comprise polymers. Hyaluronic acid (HA) is a common example used in MSN formulations. HA is advantageous as it serves as both an active targeting molecule that binds to overexpressed CD44 and as a gatekeeper molecule whose dissociation is catalyzed by the lysosomal enzyme hyaluronidase [161]. CD44 is a transmembrane glycoprotein receptor that is overexpressed in malignant cells and promotes metastatic behavior [162]. MSN formulations used HA for gatekeeping functions with great success in preclinical models [127-129]. Lysozomal pronases similarly destroyed gatekeeper networks comprising polyglutamic acid, to release chemotherapeutic payloads into breast cancer cell models [136]. While exhibiting $\mathrm{pH}$-responsiveness, gelatin is simultaneously broken down by matrix metalloproteinases (MMPs) in the extracellular tumor microenvironment. Such behavior is exploited to induce enzyme-stimulated gatekeeper degradation and subsequent controlled release from gelatin-coated MSNs in tumor tissue [127,134,135].

\subsubsection{Small Molecules}

Interactions between gatekeeper molecules and small molecules within the tumor cell or microenvironment can also stimulate controlled release of encapsulated molecules. Glutathione (GSH) is one such small molecule, residing in many tumor cell types at high concentrations, relative to healthy cells [163]. GSH works in conjunction with acidic pH environments to break disulfide bonds through redox reactions [164]. Disulfide bonds can either be used to conjugate gatekeeper molecules to MSN surfaces or contribute to gatekeeper morphology. When the disulfide bond is broken through reduction by GSH, the gatekeeper molecule leaves the MSN surface or is otherwise structurally changed to open the pores and release loaded molecules. The flexibility of using and targeting disulfide bonds promoted multiple gatekeeper options with MSNs. Cyclic peptides can be used to target tumor cells while covering pore openings until undergoing GSH reduction and becoming unstructured, thus, releasing loaded molecules [164-166]. Proteins used as gatekeepers, such as transferrin, exhibit similar behavior in the presence of GSH and can double as targeting agents [167]. The polymer HA, when bound to MSNs through disulfide bonds, also demonstrated significant effectiveness as a tumor-specific gatekeeper [130,131]. Disulfide-bound PEG gatekeepers are similarly dissociated through interaction with GSH [168]. While gatekeeper dissociation through GSH is common, other possibilities might be employed. For example, aptamers might be used as gatekeeper molecules that selectively respond to intracellular small molecules like ATP [169]. 


\subsection{External Stimuli}

While internal stimuli are abundant in vivo and provide overall ease of clinical application, external stimuli were studied as a means of controlling release from MSNs. These stimuli must be provided by clinicians following administration of MSNs. Further, pharmacokinetic considerations are necessary to apply external stimuli at times when MSN accumulation in target tissue is high. Multiple gatekeeper formulations requiring external stimuli were paired with MSNs. Primarily, these gatekeepers are thermosensitive in nature, requiring an increase of site-specific in vivo temperature [170]. Induction of localized hyperthermia results in degradation or alteration in the polymer network, releasing the payload. Preclinical methods of triggering MSN gatekeeper thermosensitive release included ultrasound [137,171-174] and laser irradiation [138,175-177].

Poly(N-isopropylacrylamide) (PNIPAM), the most studied temperature-sensitive polymer evaluated for biomedical and drug delivery applications, displays a lower critical solution temperature (LCST) at $37^{\circ} \mathrm{C}$ [141-144]. The polymer remains fully solvated below the LCST, but higher temperatures result in the polymer rapidly collapsing into a hypercoiled state. As the LCST is within the standard physiological temperature conditions, copolymers are often included with PNIPAM to increase its LCST to the range of $40-45^{\circ} \mathrm{C}$ [142-144]. MSNs using grafted PNIPAM copolymers demonstrated phototheragnostic potential with fluorescence and photoacoustic functionality. In-situ radical polymerization strategies are employed with such formulations to increase particle loading capacity and inhibit drug leakage [142]. The mechanism of release for PNIPAM is opposite of the mechanism for $\mathrm{pH}$-sensitive polymers, where increased protonation swells the polymer coating to expose the MSN pores and release the loaded cargo. Rather, the native conditions maintain the polymer in its solvated state, which is then collapsed on exposure to external heating, rapidly collapsing the polymer shell and releasing the loaded drug. The mechanism for this release is proposed to result from the high density of grafting-from polymers. The dense polymer brushes can even grow short chains within the porous interior of the MSNs, swelling to block the pores in their hydrated state [143]. Upon exposure to external heating, the polymer brushes collapse, opening the pores to release the loaded drug. The thermosensitive behavior of PNIPAM can be maintained when properly copolymerized with other polymers, such as methacrylic acid, as shown in Figure 4.
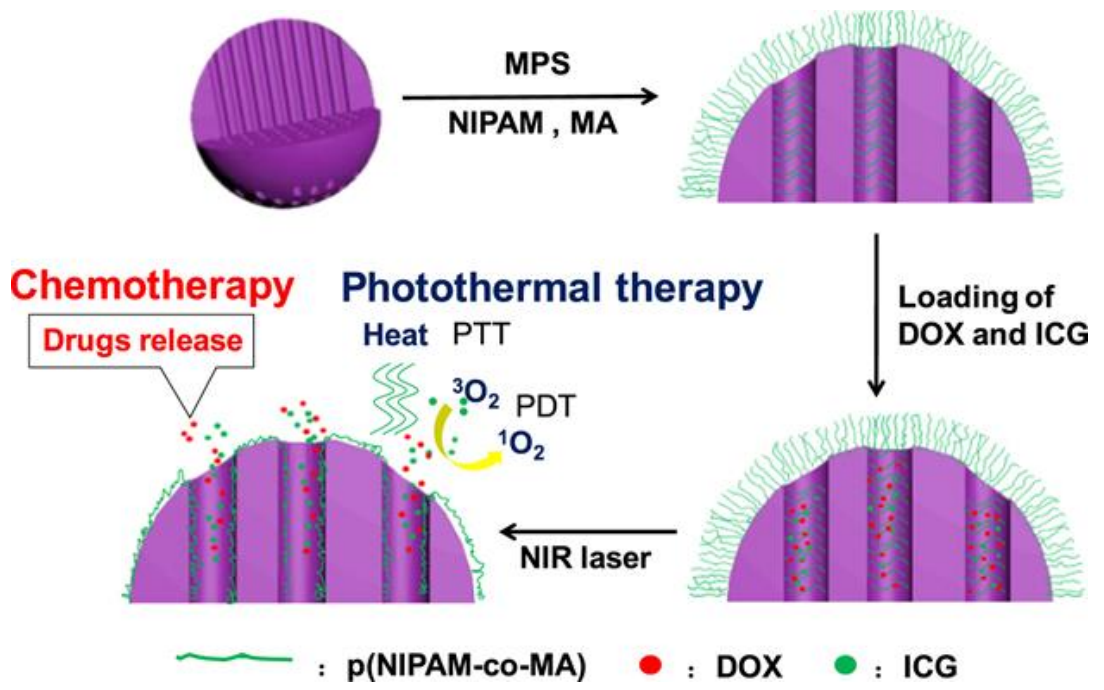

Figure 4. Loading and release of DOX and ICG from MSNs coated with PNIPAM copolymerized with methacrylic acid. The copolymer is abbreviated as p(NIPAM-co-MA). Copolymers are grafted from the surface of the MSN, generating dense brushes across the surface and into the porous interior. While the polymers are hydrated, off-target release is restricted. Upon heating by an externally applied NIR laser, the polymers collapse and release the loaded drug. Reprinted with permission from [143], Elsevier, 2018. 


\section{Targeting of MSNs and Barriers to In Vivo Efficacy}

For any NP to be clinically effective, it must reach the target site being sequestered in off-target tissue or otherwise cleared from the body. To accomplish this goal, multiple disease-site targeting strategies were implemented in preclinical nanomedicine studies. The primary options could be divided into three categories-passive targeting methods, which take advantage of innate behaviors and characteristics of diseased tissue [178]; active targeting methods, which utilize various molecular ligands that seek specific characteristics of target cells [179]; and magnetic target, which uses magnetic fields to draw susceptible NPs to disease sites [180]. While active and magnetic targeting approaches require specific design or modification of synthesized MSNs, passive targeting is assumed to be acting at all times in vivo, based on the innate physiological properties and behavior. Targeting strategies can also be combined in attempts to improve theragnostic efficacy, such as through conjugating antibodies to magnetically active NP formulations [181].

\subsection{Passive Targeting}

Diseased tissues are frequently characterized by the gaps between endothelial cells. These gaps increase endothelial permittivity to large particles, such as NPs, while having no effect on the extravasation of small molecules [182]. Subsequent residence time of NPs within the diseased tissue is theoretically increased, as compared to the small molecules based on NP size. This phenomenon, referred to as the enhanced permeability and retention (EPR) effect, remains the driving force for a significant number of NP applications, since its discovery in the 1980s [183]. Passive targeting effectiveness is primarily influenced by MSN size, shape, and surface charge [184]. While preclinical evidence supporting the efficacy of the EPR effect is vast, clinical studies showed that passively targeted NPs are not more effective than lone molecules [185-188]. The differences in efficacy in preclinical animal models and human subjects are thought to be the results of innate differences in physiology and tumor features. Irregular or lack of blood flow in solid tumor bodies along with passive targeting inability to target metastatic tumor cells are additional sources of EPR ineffectiveness [188]. While MSNs did not undergo clinical trials to assess their passive targeting effectiveness in humans, current evidence from other NP formulations suggest that active targeting is a better strategy.

\subsection{Active Targeting}

Malignant cells possess different characteristics than healthy tissue. Examples of such traits include altered metabolism, under- or overexpression of proteins and signaling molecules, or changes in gene expression. Conjugating molecules that selectively respond to these specific markers onto NP surfaces allows for active targeting of diseased cells. Attaching the MSNs to the targeting ligands can occur by multiple strategies. For example, reagents containing functional groups can be attached to MSN surfaces. These selected reagents should possess reactive functional groups that promote bond formation with the specific targeting ligand of interest ligands. For example, $\mathrm{N}$-succinimidyl (maleimidomethyl) cyclohexanecarboxylate contains a reactive amine group that forms maleimide bonds with thiol groups, such as those found on the amino acid cysteine [38]. Functional groups on the unconjugated surface of the MSNs might be similarly used for attaching active targeting ligands [64]. Non-chemical methods, such as physisorption, also demonstrated success in conjugating active targeting ligands to some MSN formulations [189].

Employing active targeting strategies significantly enhances NP accumulation near and engulfment by target cells. Several molecules were used to actively target MSNs to specific cells. While most such options utilize specific ligand-receptor interactions, a few unique cases warrant special attention. A discussion of different active targeting molecules with apparent advantages and disadvantages is provided. For additional reference, Table 2 below presents several active targeting molecule options that were successfully used with MSNs. 
Table 2. Active Targeting Molecules Used with MSNs.

\begin{tabular}{|c|c|c|c|}
\hline Molecule Class & Targeting Molecule & Method of Action & References \\
\hline \multirow[t]{5}{*}{ Proteins } & $\mathrm{mAbs}$ & Specific binding with surface antigens on target cells & [190-194] \\
\hline & Fabs & Specific binding with surface antigens on target cells & {$[195,196]$} \\
\hline & Transferrin & Binds to overexpressed transferrin receptor 1 & {$[167,197-199]$} \\
\hline & Affibodies & $\begin{array}{l}\text { Engineered proteins designed to selectively bind to } \\
\text { specific receptor on target cell }\end{array}$ & {$[61,200]$} \\
\hline & Heparin & $\begin{array}{l}\text { Anti-angiogenesis agent and ligand-receptor } \\
\text { targeting with overexpressed surface heparanase }\end{array}$ & [201] \\
\hline \multirow[t]{3}{*}{ Peptides } & RGD & Overexpressed integrin $\alpha_{V} \beta_{3}$ are selectively bound & {$[128,166,202]$} \\
\hline & pHLIPs & $\begin{array}{c}\text { Transmembrane insertion resulting from acidic } \\
\text { tumor microenvironment }\end{array}$ & {$[38,62]$} \\
\hline & CPPs & $\begin{array}{l}\text { Specific or nonspecific interaction with the cell } \\
\text { membrane or proteins on its surface }\end{array}$ & {$[189,203-209]$} \\
\hline Nucleic Acids & Aptamers & $\begin{array}{l}\text { Overexpressed surface receptor proteins (e.g., } \\
\text { GLUT1) are targeted by designed nucleic acid chains }\end{array}$ & {$[60,210-214]$} \\
\hline \multirow[t]{2}{*}{ Small Molecules } & Folate/Folic Acid & $\begin{array}{l}\text { Ligand-receptor targeting between folate and folate } \\
\text { receptor } \alpha\end{array}$ & {$[202,215-220]$} \\
\hline & Hyaluronic Acid & $\begin{array}{l}\text { Overexpressed CD44 on tumor cell surfaces binds } \\
\text { with HA }\end{array}$ & {$[88,128,221]$} \\
\hline
\end{tabular}

\subsubsection{Monoclonal Antibodies}

The most prevalently used proteins for active targeting in nanomedicine, as well as for NP-free cancer therapies, are monoclonal antibodies (mAbs). Separate from NP applications, $\mathrm{mAbs}$ are well researched and clinically used against a myriad of diseases, for decades [222-224]. mAbs possess antigen binding sites that are highly selective for surface proteins on target cells [225]. Such selectivity permits specific interactions between $\mathrm{mAbs}$ and cells presenting the surface protein of interest, while the mAbs effectively ignore cells that do not produce the target antigen. This specificity for target cells, in addition to $\mathrm{mAbs}$ is less likely to illicit immune responses, as these are derived from human B cell antibodies [225] and serves as the primary reason for choosing mAbs as targeting molecules for MSN theragnostics. If a new target protein is identified on the surface of a diseased cell, mAbs that specifically bind to it can be created [226]. For these benefits, there are notable drawbacks to using mAbs, mostly stemming from their large size, relative to other active targeting molecules. The average $\mathrm{mAb}$ is around $10 \mathrm{~nm}$ in size and has a molecular weight of $\sim 150 \mathrm{kDa}$ [227]. Such proportions affect NP performance in two ways-(1) increasing the diameter of the NP, which can alter its physiological fate, and (2) decreasing the number of $\mathrm{mAbs}$ that can bind to a single NP. The resulting lower ligand:NP ratio, relative to the ratio seen with smaller targeting ligands, can limit the targeting ability of NPs or increase the likelihood of NP sequestration by the immune system [228-230]. Despite these apparent difficulties, numerous MSN formulations utilizing $\mathrm{mAb}$ active targeting demonstrated significant tumor-specific delivery and therapeutic effect [190-194].

\subsubsection{Antibody Fragments}

To overcome the size obstacle experienced with mAbs while still taking advantage of antibody targeting capabilities, antibody antigen-binding fragments (Fabs) can be used [231,232]. Fabs are the binding domains in the variable region of the antibody [233] and, thus, are the primary targeting factor of antibody action. By using Fabs as opposed to whole antibodies, not only is the size of the entire NP reduced as compared to $\mathrm{mAb}$ conjugations, but the ligand:NP ratio is subsequently increased as well, thus increasing the likelihood of engulfment of MSNs by target cells. MSN formulations successfully used antibody fragments as their targeting components for treating or detecting preclinical ovarian cancer [195] and breast cancer models [196], respectively. 


\subsubsection{Peptides}

Similar to proteins, peptides possess the ability to selectively interact with diseased tissue cells. The primary advantage peptides have over whole proteins is their much smaller size. The smaller size promotes a more favorable ligand:NP ratio, and subsequently, a more favorable ratio of targeting ligand to target. Smaller size does impart some disadvantages, including high hydrophobicity and a lack of secondary structures, which result in less overall stability as compared to whole proteins [234,235]. Many NPs employing peptides as their active targeting agent overcome these challenges. As seen with proteins, receptorligand interactions between peptides conjugated to NP surfaces and specific receptors on target cell surfaces facilitate active targeting. A commonly used receptor-targeting peptide in NP therapies is the RGD peptide, which was shown to target upregulated integrins on tumor cells [236,237]. For tumor cells, integrins enhance proliferation, adhesion, angiogenesis, invasion, migration, and inhibition of apoptosis [238]. Integrins that promote these behaviors, namely the $\alpha_{\mathrm{v}} \beta_{3}$ integrins [239,240], are upregulated, promoting distinction between tumor cells and healthy tissue cells [241]. The ability of RGD-MSN nanovehicles to selectively target these integrins and deliver loaded molecules to tumor cells is well established in numerous studies over myriad studies, including several recent advances [128,202,242-245].

Ligand-receptor targeting is not the only method through which diseased cells might be distinguished from healthy cells. Often, diseased cells will alter the microenvironment in which they reside. For example, tumor cells increase the acidity of their extracellular environment from $\mathrm{pH} 7.4$ (e.g., standard physiological pH) to between $\mathrm{pH} 6.0-6.8[146,246]$. Largely, this phenomenon is due to the altered metabolism [145,247]. Similar acidification of the extracellular space is seen in inflamed tissues [248]. The lower $\mathrm{pH}$ around such diseased cells serves as an identifier for $\mathrm{pH}$-specific interactions between administered agents and the target cells. pH-low insertion peptides (pHLIPs) undergo significant changes in their secondary structure when exposed to (a) cellular membranes and (b) a decrease in $\mathrm{pH}$ [249-252]. This targeting mechanism operates independent of specific receptors, thus, potentially improving patient-to-patient outcomes as compared to receptor-dependent targeting options. Through conjugating pHLIPs on the outside of NPs, researchers took advantage of the $\mathrm{pH}$-specific targeting nature of these peptides [253,254]. pHLIP-conjugated silica NPs with a chitosan gatekeeper is used to treat in vitro and in vivo ovarian cancer cells through dual-action $\mathrm{pH}$-dependence, as both the pHLIPs and the chitosan selectively responded to the lower $\mathrm{pH}$ of the tumor environment [38]. Similar MSNs were used for identifying preclinical pancreatic [62] and breast cancer models [255].

Another technique for targeting diseased cells uses cell-penetrating peptides (CPPs, a.k.a. protein transduction domains or PTDs). Commonly derived from natural sources such as viruses, CPPs can act on cells in many ways. CPP action is typically independent of receptor-specific interactions. Their mechanisms does depend on the target cell type or molecules the CPPs might be carrying, among other factors [256,257]. CPPs act on cellular membranes, as a result of the hydrophobic or electrostatic interactions between the CPPs and membrane phospholipids [208]. There are two primary ways to use CPPs in NP therapies-nonspecific CPP targeting or specific CPP targeting. The former uses CPPs that can enter into nearly any cell type, while the latter employs a CPP that is specific to the diseased target cell. When using a nonspecific CPP, the peptide must be shielded or inactivated to limit NP uptake by off-target cells. When in the extracellular microenvironment of the diseased cells, the CPPs can be unveiled or activated by extracellular markers (e.g., acidic $\mathrm{pH}$ or extracellular enzymes), permitting the CPPs to act on the cells and granting NP entry [258]. Both specific and nonspecific CPPs were paired with MSNs to target myriad tumor models $[189,203-205,209]$, or to cross biological barriers such as the intestinal mucosal lining $[206,207]$. 


\subsubsection{Aptamers}

MSNs might also be functionalized with aptamers, short strands of DNA or RNA that can recognize and interact with malignant cell markers [259-261] via an active targeting mechanism. Aptamers are highly tunable, due to their 20-60 nucleotide size [262], which increases their potential to bind to myriad targets. The binding between aptamers and target receptors occurs in a manner similar to protein-receptor interactions. Generally, aptamers target upregulated or mutant proteins found on diseased cells or in the correlating extracellular microenvironments. Examples of such proteins that are successfully targeted by aptamer-functionalized MSN formulations include nucleolin [60,210], mucin-1 [211,214], HER2 [212], and PTK7 [213].

\subsubsection{Small Molecules}

The examples presented thus far demonstrate the targeting effectiveness of large biomolecules. While these larger molecules comprise a significant majority of applied active targeting strategies, small molecule approaches can also be used in targeting diseased cells [263]. The choice of small molecules for active targeting must match with an appropriate tumor receptor. As previously discussed, HA binds to the overexpressed CD44 receptors on tumor cells, making it an ideal choice for a small molecule targeting agent with MSNs $[88,221]$. It should be noted that short HA chain lengths should be used when using HA for targeting, as they increase the engulfment efficiency [264]. Tumor cell overexpression of folate receptor $\alpha$ encourage the use of folate as another small molecule active targeting option for MSNs [202,215-220].

\subsection{Magnetic Targeting}

Beyond physiological or molecular targeting options, magnetic manipulation of metallic agents can be used to induce NP accumulation at target sites. By applying magnetic fields around the desired site, NPs are attracted to the area, remaining in the tissue long enough for their action (such as delivery of loaded molecules) to occur. SPIONs are the primary component for magnetic targeting. While many approaches use such NPs alone or modified [180], MSNs can be used to encapsulate SPIONs or other iron-based NPs to take advantage of magnetic targeting $[129,265,266]$. Superparamagnetic iron oxide nanoparticles (SPIONs) are also incorporated into MSNs as a means of inducing intracellular hyperthermia, while enhancing the effect of chemotherapies [267]. There are two principle ways through which the magnetic fields can be applied to control NP accumulation-apply an external magnetic field near the target location $[268,269]$ or implant a magnetic scaffold near the target site $[270,271]$. The former method is primarily for targeting areas of minimal depth, such as near the skin, while the latter permits targeting of bones or organs deep within the body of the patient. As an example, magnetic targeting for diagnostic magnetic resonance imaging (MRI), using iron-oxide-based agents was approved for off-label use by the FDA [272,273]. Trials assessing the use of lone magnetic targeting for drug delivery, to date, did not show clinical efficacy [274,275]. The largest apparent hurdle appears to be targeting deep organs (e.g., gastrointestinal or cardiovascular systems). One proposed method to increase efficacy is to use active targeting methods in conjunction with magnetic targeting. For example, MSNs containing iron NPs and functionalized with transferrin demonstrated significant ability to cross the blood-brain barrier and deliver chemotherapeutics to brain gliomas [197].

\section{Challenges, Directions, and Conclusions}

For all the advantages that MSNs possess, several challenges need to be overcome prior to clinical translation. First, more human trials are needed to test the toxicity and clinical efficacy of agents that were shown to have more therapeutic potential than the lone molecules in preclinical animal models. The nature of passive targeting by the EPR effect in humans must be better understood to ensure a greater clinical effect of NP treatments [276]. This is especially crucial for enhancing the translation of nanomedicines 
from preclinical models (e.g., mice) to human patients. Further research into the interplay between MSN size, shape, porosity, and surface chemistry, alongside impact on tissue penetration, cellular uptake, and release kinetics is critical for optimizing MSN formulation for greatest theragnostic effect. Additionally, assessment of gatekeeper molecule toxicity and biocompatibility in humans is necessary. While such analysis was performed for some of the described gatekeeper molecules in non-gatekeeper formulations [277-281], many are yet to be tested for human safety. In order for MSN formulations to undergo FDA investigational new drug (IND) pathways, reproducibility of particles on large scales is necessary. To date, MSN formulations are synthesized in small-scale batches, limiting translation to clinical environments. Understanding the regulatory synthetic requirements for production of clinic-ready MSNs is critical, as MSN technology advances.

MSNs serve as a multifunctional platform for theragnostic nanomedicine. Innately, MSNs possess high loading capacities, stable porous structures, and high surface-to-volume ratios. Together, these characteristics provide a strong foundation for MSN encapsulation of drug or dye molecules, or even other smaller NPs. By tailoring the MSN properties during and after synthesis, in vivo behavior and clinical efficacy might be optimized. Surface modification of functional groups or application of gatekeeper molecules might prevent toxic interactions between the MSN core and the host environment. Simultaneously, the gatekeeper controls the encapsulation and release of loaded molecules in a stimuli-specific manner. The ability to functionalize MSNs with various targeting options is also highly favorable for enhancing clinical outcomes. Many active targeting strategies demonstrated significant preclinical potential with MSNs, with limited off-target accumulation. Based on the current body of evidence, MSNs that are within the 20-80 $\mathrm{nm}$ diameter range paired with stimuli-responsive gatekeepers and active targeting moieties, might operate as the most clinically beneficial formulation. As research continues to address the apparent presented obstacles, MSN formulations will see growing prominence in clinical nanomedicine, which might correlate to enhanced clinical outcomes and patient care.

Funding: This work was supported by NIH grants R01CA212350, R01EB020125, and R01CA205941.

Conflicts of Interest: The authors declare no conflict of interest.

$\begin{array}{ll}\text { Abbreviations } \\ \text { NP } & \text { Nanoparticle } \\ \text { MSN } & \text { Mesoporous Silica Nanoparticle } \\ \text { CTAB } & \text { Hexadecyltrimethylammonium Bromide } \\ \text { TEOS } & \text { Tetraethyl Orthosilicate } \\ \text { TPOS } & \text { Tetrapropyl Orthosilicate } \\ \text { TMOS } & \text { Tetramethyl Orthosilicate } \\ \text { SAM } & \text { Self-assembled Monolayer } \\ \text { DLS } & \text { Dynamic Light Scattering } \\ \text { TEM } & \text { Transmission Electron Microscopy } \\ \text { BET } & \text { Brunauer-Emmett-Teller } \\ \text { RES } & \text { Reticuloendothelial System } \\ \text { AR } & \text { Aspect Ratio } \\ \text { TEA } & \text { Triethylanolamine } \\ \text { PEG } & \text { Poly(ethylene glycol) } \\ \text { CRP } & \text { Controlled Radical Polymerization } \\ \text { ATRP } & \text { Atom Transfer Radical Polymerization } \\ \text { RAFT } & \text { Reversible Addition/Fragmentation Chain Transfer } \\ \text { NMP } & \text { Nitroxide-Mediated Polymerization } \\ \text { HA } & \text { Hyaluronic Acid } \\ \text { MMP } & \text { Matrix Metalloproteinase } \\ \text { GSH } & \text { Glutathione } \\ \text { PNIPAM } & \text { Poly(N-isopropylacrylamide) } \\ \text { LCST } & \text { Lower Critical Solution Temperature } \\ & \end{array}$




$\begin{array}{ll}\mathrm{EPR} & \text { Enhanced Permeability and Retention } \\ \mathrm{mAb} & \text { Monoclonal Antibody } \\ \mathrm{Fab} & \text { Antibody Fragment } \\ \text { pHLIP } & \text { pH-low Insertion Peptide } \\ \mathrm{CPP} & \text { Cell Penetrating Peptide } \\ \text { SPION } & \text { Superparamagnetic Iron Oxide Nanoparticle } \\ \text { MRI } & \text { Magnetic Resonance Imaging } \\ \text { IND } & \text { Investigational New Drug }\end{array}$

\section{References}

1. Asefa, T.; Tao, Z. Biocompatibility of mesoporous silica nanoparticles. Chem. Res. Toxicol. 2012, 25, 2265-2284. [CrossRef]

2. Qiao, Z.-A.; Zhang, L.; Guo, M.; Liu, Y.; Huo, Q. Synthesis of mesoporous silica nanoparticles via controlled hydrolysis and condensation of silicon alkoxide. Chem. Mater. 2009, 21, 3823-3829. [CrossRef]

3. Lodha, A.; Lodha, M.; Patel, A.; Chaudhuri, J.; Dalal, J.; Edwards, M.; Douroumis, D. Synthesis of mesoporous silica nanoparticles and drug loading of poorly water soluble drug cyclosporin A. J. Pharm. Bioallied Sci. 2012, 4, 92-94. [CrossRef] [PubMed]

4. Wen, J.; Yang, K.; Liu, F.; Li, H.; Xu, Y.; Sun, S. Diverse gatekeepers for mesoporous silica nanoparticle based drug delivery systems. Chem. Soc. Rev. 2017, 46, 6024-6045. [CrossRef] [PubMed]

5. Phillips, E.; Penate-Medina, O.; Zanzonico, P.B.; Carvajal, R.D.; Mohan, P.; Ye, Y.; Humm, J.; Gönen, M.; Kalaigian, H.; Schöder, H.; et al. Clinical translation of an ultrasmall inorganic optical-PET imaging nanoparticle probe. Sci. Transl. Med. 2014, 6, $260 \mathrm{ra149.}$ [CrossRef] [PubMed]

6. Anselmo, A.C.; Mitragotri, S. Nanoparticles in the clinic. Bioeng. Transl. Med. 2016, 1, 10-29. [CrossRef]

7. Farjadian, F.; Roointan, A.; Mohammadi-Samani, S.; Hosseini, M. Mesoporous silica nanoparticles: Synthesis, pharmaceutical applications, biodistribution, and biosafety assessment. Chem. Eng. J. 2019, 359, 684-705. [CrossRef]

8. Narayan, R.; Nayak, U.Y.; Raichur, A.M.; Garg, S. Mesoporous silica nanoparticles: A comprehensive review on synthesis and recent advances. Pharmaceutics 2018, 10, 118. [CrossRef]

9. Trewyn, B.G.; Slowing, I.I.; Giri, S.; Chen, H.-T.; Lin, V.S.-Y. Synthesis and functionalization of a mesoporous silica nanoparticle based on the sol-gel process and applications in controlled release. Acc. Chem. Res. 2007, 40, 846-853. [CrossRef]

10. Ernawati, L.; Balgis, R.; Ogi, T.; Okuyama, K. Tunable synthesis of mesoporous silica particles with unique radially oriented pore structures from tetramethyl orthosilicate via oil-water emulsion process. Langmuir 2017, 33, 783-790. [CrossRef]

11. Ernawati, L.; Ogi, T.; Balgis, R.; Okuyama, K.; Stucki, M.; Hess, S.C.; Stark, W.J. Hollow silica as an optically transparent and thermally insulating polymer additive. Langmuir 2015, 32, 338-345. [CrossRef] [PubMed]

12. Vazquez, N.I.; Gonzalez, Z.; Ferrari, B.; Castro, Y. Synthesis of mesoporous silica nanoparticles by sol-gel as nanocontainer for future drug delivery applications. Boletín Soc. Española Cerámica Vidr. 2017, 56, 139-145. [CrossRef]

13. Jafari, S.; Derakhshankhah, H.; Alaei, L.; Fattahi, A.; Varnamkhasti, B.S.; Saboury, A.A. Mesoporous silica nanoparticles for therapeutic/diagnostic applications. Biomed. Pharmacother. 2019, 109, 1100-1111. [CrossRef] [PubMed]

14. Isomaa, B.; Reuter, J.; Djupsund, B.M. The subacute and chronic toxicity of cetyltrimethylammonium bromide (CTAB), a cationic surfactant, in the rat. Arch. Toxicol. 1976, 35, 91-96. [CrossRef]

15. Yildirim, A.; Turkaydin, M.; Garipcan, B.; Bayindir, M. Cytotoxicity of multifunctional surfactant containing capped mesoporous silica nanoparticles. RSC Adv. 2016, 6, 32060-32069. [CrossRef]

16. Hudson, S.P.; Padera, R.F.; Langer, R.; Kohane, D.S. The biocompatibility of mesoporous silicates. Biomaterials 2008, 29 , 4045-4055. [CrossRef] [PubMed]

17. He, Q.; Zhang, Z.; Gao, Y.; Shi, J.; Li, Y. intracellular localization and cytotoxicity of spherical mesoporous silica nano- and microparticles. Small 2009, 5, 2722-2729. [CrossRef]

18. Urata, C.; Aoyama, Y.; Tonegawa, A.; Yamauchi, Y.; Kuroda, K. Dialysis process for the removal of surfactants to form colloidal mesoporous silica nanoparticles. Chem. Commun. 2009, 5094-5096. [CrossRef] [PubMed]

19. Park, K.-W.; Kim, J.-Y.; Seo, H.-J.; Kwon, O.-Y. Preparation of mesoporous silica by nonionic surfactant micelle-templated gelation of $\mathrm{Na}_{2} \mathrm{SiO}_{3}$ and $\mathrm{H}_{2} \mathrm{SiF}_{6}$ and application as a catalyst carrier for the partial oxidation of CH. Sci. Rep. 2019, 9, 1-8. [CrossRef]

20. Kango, S.; Kalia, S.; Celli, A.; Njuguna, J.; Habibi, Y.; Kumar, R. Surface modification of inorganic nanoparticles for development of organic-inorganic nanocomposites-A review. Prog. Polym. Sci. 2013, 38, 1232-1261. [CrossRef]

21. Yegorov, A.S.; Ivanov, V.S.; Antipov, A.V.; Wozniak, A.I.; Tcarkova, K.V. Chemical modification methods of nanoparticles of silicon carbide surface (review). Orient. J. Chem. 2015, 31, 1269-1275. [CrossRef]

22. Love, J.C.; Estroff, L.A.; Kriebel, J.K.; Nuzzo, R.G.; Whitesides, G.M. Self-assembled monolayers of thiolates on metals as a form of nanotechnology. Chem. Rev. 2005, 105, 1103-1170. [CrossRef] [PubMed]

23. Stetefeld, J.; McKenna, S.A.; Patel, T.R. Dynamic light scattering: A practical guide and applications in biomedical sciences. Biophys. Rev. 2016, 8, 409-427. [CrossRef]

24. Xu, Y.; Xiao, L.; Chang, Y.; Cao, Y.; Chen, C.; Wang, D. pH and redox dual-responsive MSN-S-S-CS as a drug delivery system in cancer therapy. Materials 2020, 13, 1279. [CrossRef] [PubMed] 
25. Deen, W.M.; Lazzara, M.J.; Myers, B.D. Structural determinants of glomerular permeability. Am. J. Physiol. Physiol. 2001, 281, F579-F596. [CrossRef] [PubMed]

26. Ohlson, M.; Sörensson, J.; Haraldsson, B. A gel-membrane model of glomerular charge and size selectivity in series. Am. J. Physiol. Physiol. 2001, 280, F396-F405. [CrossRef]

27. Thomas, O.S.; Weber, W. Overcoming physiological barriers to nanoparticle delivery-Are we there yet? Front. Bioeng. Biotechnol. 2019, 7, 415. [CrossRef] [PubMed]

28. Chen, K.-H.; Lundy, D.J.; Toh, E.K.-W.; Chen, C.-H.; Shih, C.H.-L.; Chen, P.; Chang, H.-C.; Lai, J.J.; Stayton, P.S.; Hoffman, A.S.; et al. Nanoparticle distribution during systemic inflammation is size-dependent and organ-specific. Nanoscale 2015, 7, 15863-15872. [CrossRef]

29. Attia, M.F.; Anton, N.; Wallyn, J.; Omran, Z.; Vandamme, T.F. An overview of active and passive targeting strategies to improve the nanocarriers efficiency to tumour sites. J. Pharm. Pharmacol. 2019, 71, 1185-1198. [CrossRef]

30. Nie, S. Understanding and overcoming major barriers in cancer nanomedicine. Nanomedicine 2010, 5, 523-528. [CrossRef]

31. Li, S.-D.; Huang, L. Nanoparticles evading the reticuloendothelial system: Role of the supported bilayer. Biochim. Biophys. Acta (BBA) Biomembr. 2009, 1788, 2259-2266. [CrossRef]

32. Abstiens, K.; Gregoritza, M.; Goepferich, A.M. Ligand density and linker length are critical factors for multivalent nanoparticleReceptor interactions. ACS Appl. Mater. Interfaces 2018, 11, 1311-1320. [CrossRef]

33. Zhang, S.; Li, J.; Lykotrafitis, G.; Bao, G.; Suresh, S. Size-dependent endocytosis of nanoparticles. Adv. Mater. 2009, 21, 419-424. [CrossRef]

34. Yang, Y.; Yu, C. Advances in silica based nanoparticles for targeted cancer therapy. Nanomed. Nanotechnol. Biol. Med. 2016, 12, 317-332. [CrossRef]

35. Bouchoucha, M.; Côté, M.-F.; C.-Gaudreault, R.; Fortin, M.-A.; Kleitz, F. Size-controlled functionalized mesoporous silica nanoparticles for tunable drug release and enhanced anti-tumoral activity. Chem. Mater. 2016, 28, 4243-4258. [CrossRef]

36. Dogra, P.; Adolphi, N.L.; Wang, Z.; Lin, Y.-S.; Butler, K.S.; Durfee, P.N.; Croissant, J.G.; Noureddine, A.; Coker, E.N.; Bearer, E.L.; et al. Establishing the effects of mesoporous silica nanoparticle properties on in vivo disposition using imaging-based pharmacokinetics. Nat. Commun. 2018, 9, 1-14. [CrossRef]

37. He, Q.; Zhang, Z.; Gao, F.; Li, Y.; Shi, J. In vivo Biodistribution and urinary excretion of mesoporous silica nanoparticles: Effects of particle size and PEGylation. Small 2010, 7, 271-280. [CrossRef] [PubMed]

38. Samykutty, A.; Grizzle, W.E.; Fouts, B.L.; McNally, M.W.; Chuong, P.; Thomas, A.; Chiba, A.; Otali, D.; Woloszynska, A.; Said, N.; et al. Optoacoustic imaging identifies ovarian cancer using a microenvironment targeted theranostic wormhole mesoporous silica nanoparticle. Biomaterials 2018, 182, 114-126. [CrossRef] [PubMed]

39. Gunawan, C.; Lim, M.; Marquis, C.P.; Amal, R. Nanoparticle-protein corona complexes govern the biological fates and functions of nanoparticles. J. Mater. Chem. B 2014, 2, 2060-2083. [CrossRef] [PubMed]

40. Shukhnova, A.; Bozrova, S.; Sokolov, P.; Berestovoy, M.; Karaulov, A.; Nabiev, I. Dependence of nanoparticle toxicity on their physical and chemical properties. Nanoscale Res. Lett. 2018, 13, 1-21. [CrossRef]

41. Ajdary, M.; Moosavi, M.A.; Rahmati, M.; Falahati, M.; Mahboubi, M.; Mandegary, A.; Jangjoo, S.; Mohammadinejad, R.; Varma, R.S. Health concerns of various nanoparticles: A review of their in vitro and in vivo toxicity. Nanomaterials 2018, 8, 634. [CrossRef] [PubMed]

42. Lundqvist, M.; Augustsson, C.; Lilja, M.; Lundkvist, K.; Dahlbäck, B.; Linse, S.; Cedervall, T. The nanoparticle protein corona formed in human blood or human blood fractions. PLoS ONE 2017, 12, e0175871. [CrossRef] [PubMed]

43. Elechalawar, C.K.; Hossen, N.; McNally, L.; Bhattacharya, R.; Mukherjee, P. Analysing the nanoparticle-protein corona for potential molecular target identification. J. Control. Release 2020, 322, 122-136. [CrossRef] [PubMed]

44. Marichal, L.; Klein, G.; Armengaud, J.; Boulard, Y.; Chédin, S.; Labarre, J.; Pin, S.; Renault, J.-P.; Aude, J.-C. Protein Corona Composition of Silica Nanoparticles in Complex Media: Nanoparticle Size does not Matter. Nanomaterials 2020, 10, 240. [CrossRef]

45. Wolfram, J.; Zhu, M.; Yang, Y.; Shen, J.; Gentile, E.; Paolino, D.; Fresta, M.; Nie, G.; Chen, C.; Shen, H.; et al. Safety of nanoparticles in medicine. Curr. Drug Targets 2015, 16, 1671-1681. [CrossRef] [PubMed]

46. Ge, C.; Tian, J.; Zhao, Y.; Chen, C.; Zhou, R.; Chai, Z. Towards understanding of nanoparticle-protein corona. Arch. Toxicol. 2015, 89, 519-539. [CrossRef]

47. Barbero, F.; Russo, L.; Vitali, M.; Piella, J.; Salvo, I.; Borrajo, M.L.; Busquets-Fité, M.; Grandori, R.; Bastús, N.G.; Casals, E.; et al. Formation of the protein corona: The interface between nanoparticles and the immune system. Semin. Immunol. 2017, 34, 52-60. [CrossRef]

48. Corbo, C.; Molinaro, R.; Parodi, A.; Toledano Furman, N.E.; Salvatore, F.; Tasciotti, E. The impact of nanoparticle protein corona on cytotoxicity, immunotoxicity, and target drug delivery. Nanomedicine 2016, 11, 81-100. [CrossRef]

49. Clemments, A.M.; Muniesa, C.; Landry, C.C.; Botella, P. Effect of surface properties in protein corona development on mesoporous silica nanoparticles. RSC Adv. 2014, 4, 29134-29138. [CrossRef]

50. Safavi-Sohi, R.; Ghassempour, A. Effects of surface chemistry modification using zwitterionic coatings on the surface of silica nanoparticles on prevention of protein corona: A test study. Nanomed. Res. J. 2018, 3, 89-95. [CrossRef]

51. Oh, J.Y.; Kim, H.S.; Palanikumar, L.; Go, E.M.; Jana, B.; Park, S.A.; Kim, H.Y.; Kim, K.; Seo, J.K.; Kwak, S.K.; et al. Cloaking nanoparticles with protein corona shield for targeted drug delivery. Nat. Commun. 2018, 9, 1-9. [CrossRef] [PubMed] 
52. Rahmani, S.; Durand, J.-O.; Charnay, C.; Lichon, L.; Férid, M.; Garcia, M.; Gary-Bobo, M. Synthesis of mesoporous silica nanoparticles and nanorods: Application to doxorubicin delivery. Solid State Sci. 2017, 68, 25-31. [CrossRef]

53. Meng, H.; Yang, S.; Li, Z.; Xia, T.; Chen, J.; Ji, Z.; Zhang, H.; Wang, X.; Lin, S.; Huang, C.; et al. Aspect ratio determines the quantity of mesoporous silica nanoparticle uptake by a small GTPase-dependent macropinocytosis mechanism. ACS Nano 2011, 5, 4434-4447. [CrossRef] [PubMed]

54. Chauhan, V.P.; Popović, Z.; Chen, O.; Cui, J.; Fukumura, D.; Bawendi, M.G.; Jain, R.K. Fluorescent nanorods and nanospheres for real-time in vivo probing of nanoparticle shape-dependent tumor penetration. Angew. Chem. Int. Ed. 2011, 50, 11417-11420. [CrossRef] [PubMed]

55. Zhao, Y.; Wang, Y.; Ran, F.; Cui, Y.; Liu, C.; Zhao, Q.; Gao, Y.; Wang, D.; Wang, S. A comparison between sphere and rod nanoparticles regarding their in vivo biological behavior and pharmacokinetics. Sci. Rep. 2017, 7, 1-11. [CrossRef] [PubMed]

56. Trewyn, B.G.; Nieweg, J.A.; Zhao, Y.; Lin, V.S.-Y. Biocompatible mesoporous silica nanoparticles with different morphologies for animal cell membrane penetration. Chem. Eng. J. 2008, 137, 23-29. [CrossRef]

57. Decuzzi, P.; Godin, B.; Tanaka, T.; Lee, S.-Y.; Chiappini, C.; Liu, X.; Ferrari, M. Size and shape effects in the biodistribution of intravascularly injected particles. J. Control. Release 2010, 141, 320-327. [CrossRef] [PubMed]

58. Xu, C.; Niu, Y.; Popat, A.; Jambhrunkar, S.; Karmakar, S.; Yu, C. Rod-like mesoporous silica nanoparticles with rough surfaces for enhanced cellular delivery. J. Mater. Chem. B 2014, 2, 253-256. [CrossRef] [PubMed]

59. Wang, W.; Wang, P.; Tang, X.; Elzatahry, A.A.; Wang, S.; Al-Dahyan, D.; Zhao, M.; Mengyao, Z.; Hung, C.-T.; Zhu, X.; et al. Facile synthesis of uniform virus-like mesoporous silica nanoparticles for enhanced cellular internalization. ACS Central Sci. 2017, 3 , 839-846. [CrossRef]

60. Babaeia, M.; Abnousad, K.; Taghdisibc, S.; Taghavia, S.; Saljooghi, A.S.; Ramezaniace, M.; Alibolandiac, M. Targeted rod-shaped mesoporous silica nanoparticles for the co-delivery of camptothecin and survivin shRNA in to colon adenocarcinoma in vitro and in vivo. Eur. J. Pharm. Biopharm. 2020, 156, 84-96. [CrossRef]

61. Gurka, M.K.; Pender, D.; Chuong, P.; Fouts, B.L.; Sobelov, A.; McNally, M.W.; Mezera, M.; Woo, S.Y.; McNally, L.R. Identification of pancreatic tumors in vivo with ligand-targeted, $\mathrm{pH}$ responsive mesoporous silica nanoparticles by multispectral optoacoustic tomography. J. Control. Release 2016, 231, 60-67. [CrossRef]

62. Zeiderman, M.R.; Morgan, D.E.; Christein, J.D.; Grizzle, W.E.; McMasters, K.M.; McNally, L.R. Acidic pH-targeted chitosan-capped mesoporous silica coated gold nanorods facilitate detection of pancreatic tumors via multispectral optoacoustic tomography. ACS Biomater. Sci. Eng. 2016, 2, 1108-1120. [CrossRef]

63. Möller, K.; Kobler, J.; Bein, T. Colloidal suspensions of nanometer-sized mesoporous Silica. Adv. Funct. Mater. 2007, 17, 605-612. [CrossRef]

64. Jambhrunkar, S.; Yu, M.; Yang, J.; Zhang, J.; Shrotri, A.; Endo-Munoz, L.; Moreau, J.; Lu, G.; Yu, C. Stepwise pore size reduction of ordered nanoporous silica materials at angstrom precision. J. Am. Chem. Soc. 2013, 135, 8444-8447. [CrossRef]

65. Liberman, A.; Mendez, N.; Trogler, W.C.; Kummel, A.C. Synthesis and surface functionalization of silica nanoparticles for nanomedicine. Surf. Sci. Rep. 2014, 69, 132-158. [CrossRef] [PubMed]

66. Lin, Y.-S.; Haynes, C.L. Impacts of mesoporous silica nanoparticle size, pore ordering, and pore integrity on hemolytic activity. J. Am. Chem. Soc. 2010, 132, 4834-4842. [CrossRef] [PubMed]

67. Alessandrini, F.; Pimentel, J.A.A.; Landsiedel, R.; Wohlleben, W.; Mempel, M.; Marzaioli, V.; Weichenmeier, I.; Luxenhofer, G.; Wiemann, M.; Eiden, S.; et al. Surface modifications of silica nanoparticles are crucial for their inert versus proinflammatory and immunomodulatory properties. Int. J. Nanomed. 2014, 9, 2815-2832. [CrossRef]

68. Mahmoud, A.M.; Desouky, E.M.; Hozayen, W.G.; Bin-Jumah, M.; El-Nahass, E.-S.; Soliman, H.A.; Farghali, A.A. Mesoporous silica nanoparticles trigger liver and kidney injury and fibrosis via altering TLR4/NF-kB, JAK2/STAT3 and Nrf2/HO-1 signaling in rats. Biomolecules 2019, 9, 528. [CrossRef]

69. Pavan, C.; Piane, M.D.; Gullo, M.; Filippi, F.; Fubini, B.; Hoet, P.; Horwell, C.J.; Huaux, F.; Lison, D.; Giudice, C.L.; et al. The puzzling issue of silica toxicity: Are silanols bridging the gaps between surface states and pathogenicity? Part. Fibre Toxicol. 2019, 16, 1-10. [CrossRef] [PubMed]

70. Singappuli-Arachchige, D.; Slowing, I.I. Control of interfacial $\mathrm{pH}$ in mesoporous silica nanoparticles via surface functionalization. J. Chem. Phys. 2020, 152, 034703. [CrossRef]

71. Zhuravlev, L.T.; Potapov, V.V. Density of silanol groups on the surface of silica precipitated from a hydrothermal solution. Russ. J. Phys. Chem. A 2006, 80, 1119-1128. [CrossRef]

72. Cao, L.; Zhou, Z.; Niu, S.; Cao, C.; Li, X.; Shan, Y.; Huang, Q. Positive-charge functionalized mesoporous silica nanoparticles as nanocarriers for controlled 2,4-dichlorophenoxy acetic acid sodium salt release. J. Agric. Food Chem. 2018, 66, 6594-6603. [CrossRef] [PubMed]

73. Blanco, E.; Shen, H.; Ferrari, M. Principles of nanoparticle design for overcoming biological barriers to drug delivery. Nat. Biotechnol. 2015, 33, 941-951. [CrossRef]

74. Fröhlich, E. The role of surface charge in cellular uptake and cytotoxicity of medical nanoparticles. Int. J. Nanomed. 2012, 7, 5577-5591. [CrossRef]

75. Hosseinpour, S.; Walsh, L.J.; Xu, C. Biomedical application of mesoporous silica nanoparticles as delivery systems: A biological safety perspective. J. Mater. Chem. B 2020, 8, 9863-9876. [CrossRef] 
76. Yildirim, A.; Ozgur, E.; Bayindir, M. Impact of mesoporous silica nanoparticle surface functionality on hemolytic activity, thrombogenicity and non-specific protein adsorption. J. Mater. Chem. B 2013, 1, 1909-1920. [CrossRef]

77. Kim, S.-K.; Kim, J.-H.; Kim, C.-S.; Ignacio, R.M.C.; Kim, D.-H.; Sajo, M.E.J.; Meang, E.-H.; Qi, X.-F.; Park, S.-E.; Kim, Y.-R.; et al. Immunotoxicity of silicon dioxide nanoparticles with different sizes and electrostatic charge. Int. J. Nanomed. 2014, 9, 183-193. [CrossRef]

78. Chen, L.; Liu, J.; Zhang, Y.; Zhang, G.; Kang, Y.; Chen, A.; Feng, X.; Shao, L. The toxicity of silica nanoparticles to the immune system. Nanomedicine 2018, 13, 1939-1962. [CrossRef] [PubMed]

79. Niculescu, V.-C. Mesoporous silica nanoparticles for bio-applications. Front. Mater. 2020, 7. [CrossRef]

80. Shi, H.; Liu, S.; Cheng, J.; Yuan, S.; Yang, Y.; Fang, T.; Cao, K.; Wei, K.; Zhang, Q.; Liu, Y. Charge-selective delivery of proteins using mesoporous silica nanoparticles fused with lipid bilayers. ACS Appl. Mater. Interfaces 2019, 11, 3645-3653. [CrossRef] [PubMed]

81. Nabeshi, H.; Yoshikawa, T.; Arimori, A.; Yoshida, T.; Tochigi, S.; Hirai, T.; Akase, T.; Nagano, K.; Abe, Y.; Kamada, H.; et al. Effect of surface properties of silica nanoparticles on their cytotoxicity and cellular distribution in murine macrophages. Nanoscale Res. Lett. 2011, 6, 93. [CrossRef] [PubMed]

82. Lankoff, A.; Arabski, M.; Wegierek-Ciuk, A.; Kruszewski, M.; Lisowska, H.; Banasik-Nowak, A.; Rozga-Wijas, K.; Wojewodzka, M.; Slomkowski, S. Effect of surface modification of silica nanoparticles on toxicity and cellular uptake by human peripheral blood lymphocytesin vitro. Nanotoxicology 2012, 7, 235-250. [CrossRef] [PubMed]

83. Natarajan, S.K.; Selvaraj, S. Mesoporous silica nanoparticles: Importance of surface modifications and its role in drug delivery. RSC Adv. 2014, 4, 14328-14334. [CrossRef]

84. Dai, T.; Tanaka, M.; Huang, Y.-Y.; Hamblin, M.R. Chitosan preparations for wounds and burns: Antimicrobial and wound-healing effects. Expert Rev. Anti-Infect. Ther. 2011, 9, 857-879. [CrossRef] [PubMed]

85. Bukhari, S.N.A.; Roswandi, N.L.; Waqas, M.; Habib, H.; Hussain, F.; Khan, S.; Sohail, M.; Ramli, N.A.; Thu, H.E.; Hussain, Z. Hyaluronic acid, a promising skin rejuvenating biomedicine: A review of recent updates and pre-clinical and clinical investigations on cosmetic and nutricosmetic effects. Int. J. Biol. Macromol. 2018, 120, 1682-1695. [CrossRef] [PubMed]

86. Cui, L.; Liu, W.; Liu, H.; Qin, Q.; Wu, S.; He, S.; Pang, X.; Zhu, C.; Shen, P. pH-triggered charge-reversal mesoporous silica nanoparticles stabilized by chitosan oligosaccharide/carboxymethyl chitosan hybrids for effective intracellular delivery of doxorubicin. ACS Appl. Bio Mater. 2019, 2, 1907-1919. [CrossRef]

87. Kean, T.; Thanou, M. Biodegradation, biodistribution and toxicity of chitosan. Adv. Drug Deliv. Rev. 2010, 62, 3-11. [CrossRef]

88. Yu, M.; Jambhrunkar, S.; Thorn, P.; Chen, J.; Gu, W.; Yu, C. Hyaluronic acid modified mesoporous silica nanoparticles for targeted drug delivery to CD44-overexpressing cancer cells. Nanoscale 2012, 5, 178-183. [CrossRef] [PubMed]

89. Hong, S.; Kim, K.Y.; Wook, H.J.; Park, S.Y.; Lee, K.D.; Lee, D.Y.; Lee, H. Attenuation of thein vivotoxicity of biomaterials by polydopamine surface modification. Nanomedicine 2011, 6, 793-801. [CrossRef]

90. Bilalis, P.; Tziveleka, L.-A.; Varlas, S.; Iatrou, H. pH-Sensitive nanogates based on poly(l-histidine) for controlled drug release from mesoporous silica nanoparticles. Polym. Chem. 2016, 7, 1475-1485. [CrossRef]

91. Gachoka, D. Polyethylene Glycol (PEG)-induced anaphylactic reaction during bowel preparation. ACG Case Rep. J. 2015, 2, 216-218. [CrossRef] [PubMed]

92. Cerdá, V.J.; Pacheco, R.R.; Witek, J.D.; De La Calle, F.M.M.; Fernández, M.L.D.L.S. Immediate hypersensitivity to polyethylene glycols in unrelated products: When standardization in the nomenclature of the components of drugs, cosmetics, and food becomes necessary. Allergy Asthma Clin. Immunol. 2019, 15, 9. [CrossRef] [PubMed]

93. Li, Y.; Wang, L.; Natarajan, B.; Tao, P.; Benicewicz, B.C.; Ullal, C.; Schadler, L.S. Bimodal "matrix-free" polymer nanocomposites. RSC Adv. 2015, 5, 14788-14795. [CrossRef]

94. Zhao, D.; Di Nicola, M.; Khani, M.M.; Jestin, J.; Benicewicz, B.C.; Kumar, S.K. Role of block copolymer adsorption versus bimodal grafting on nanoparticle self-assembly in polymer nanocomposites. Soft Matter 2016, 12, 7241-7247. [CrossRef]

95. Mu, S.; Liu, Y.; Wang, T.; Zhang, J.; Jiang, D.; Yu, X.; Zhang, N. Unsaturated nitrogen-rich polymer poly(l-histidine) gated reversibly switchable mesoporous silica nanoparticles using "graft to" strategy for drug controlled release. Acta Biomater. 2017, 63, 150-162. [CrossRef] [PubMed]

96. Paris, J.L.; Villaverde, G.; Cabañas, M.V.; Manzano, M.; Vallet-Regí, M.; Cabañas, V. From proof-of-concept material to PEGylated and modularly targeted ultrasound-responsive mesoporous silica nanoparticles. J. Mater. Chem. B 2018, 6, 2785-2794. [CrossRef]

97. Gonçalves, J.L.M.; Castanheira, E.J.; Alves, S.P.C.; Baleizão, C.; Farinha, J.P. Grafting with RAFT—gRAFT strategies to prepare hybrid nanocarriers with core-shell architecture. Polymers 2020, 12, 2175. [CrossRef]

98. Wang, Y. ATRP of methyl acrylate by continuous feeding of activators giving polymers with predictable end-group fidelity. Polymers 2019, 11, 1238. [CrossRef] [PubMed]

99. Discekici, E.H.; Anastasaki, A.; De Alaniz, J.R.; Hawker, C.J. Evolution and Future Directions of Metal-Free Atom Transfer Radical Polymerization. Macromolecules 2018, 51, 7421-7434. [CrossRef]

100. Anastasaki, A.; Nikolaou, V.; Haddleton, D.M. Cu(0)-mediated living radical polymerization: Recent highlights and applications; a perspective. Polym. Chem. 2016, 7, 1002-1026. [CrossRef]

101. Wang, Y.; Wang, Q.; Pan, X. Controlled radical polymerization toward ultra-high molecular weight by rationally designed borane radical initiators. Cell Rep. Phys. Sci. 2020, 1, 100073. [CrossRef] 
102. Rodlert, M.; Harth, E.; Rees, I.; Hawker, C.J. End-group fidelity in nitroxide-mediated living free-radical polymerizations. J. Polym. Sci. Part A Polym. Chem. 2000, 38, 4749-4763. [CrossRef]

103. Beagan, A.M.; Alghamdi, A.A.; Lahmadi, S.S.; Halwani, M.A.; Almeataq, M.S.; AlHazaa, A.N.; Alotaibi, K.M.; Alswieleh, A.M. Folic acid-terminated poly (2-diethyl amino ethyl methacrylate) brush-gated magnetic mesoporous nanoparticles as a smart drug delivery system. Polymers 2020, 13, 59. [CrossRef]

104. Wu, L.; Glebe, U.; Böker, A. Surface-initiated controlled radical polymerizations from silica nanoparticles, gold nanocrystals, and bionanoparticles. Polym. Chem. 2015, 6, 5143-5184. [CrossRef]

105. Huang, L.; Liu, M.; Mao, L.; Huang, Q.; Huang, H.; Zeng, G.; Tian, J.; Wen, Y.; Zhang, X.; Wei, Y. A facile FeBr 3 based photoATRP for surface modification of mesoporous silica nanoparticles for controlled delivery cisplatin. Appl. Surf. Sci. 2018, 434, 204-210. [CrossRef]

106. Dadashi-Silab, S.; Szczepaniak, G.; Lathwal, S.; Matyjaszewski, K. Iodine-mediated photoATRP in aqueous media with oxygen tolerance. Polym. Chem. 2020, 11, 843-848. [CrossRef]

107. Suk, J.S.; Xu, Q.; Kim, N.; Hanes, J.; Ensign, L.M. PEGylation as a strategy for improving nanoparticle-based drug and gene delivery. Adv. Drug Deliv. Rev. 2016, 99, 28-51. [CrossRef] [PubMed]

108. Wani, A.; Savithra, G.H.L.; Abyad, A.; Kanvinde, S.; Li, J.; Brock, S.; Oupický, D. Surface PEGylation of Mesoporous Silica Nanorods (MSNR): Effect on loading, release, and delivery of mitoxantrone in hypoxic cancer cells. Sci. Rep. 2017, 7, 2274. [CrossRef]

109. Cho, Y.; Shi, R.; Borgens, R.B.; Ivanisevic, A. Functionalized mesoporous silica nanoparticle-based drug delivery system to rescue acrolein-mediated cell death. Nanomedicine 2008, 3, 507-519. [CrossRef] [PubMed]

110. Hanafi-Bojd, M.Y.; Jaafari, M.R.; Ramezanian, N.; Xue, M.; Amin, M.; Shahtahmassebi, N.; Malaekeh-Nikouei, B. Surface functionalized mesoporous silica nanoparticles as an effective carrier for epirubicin delivery to cancer cells. Eur. J. Pharm. Biopharm. 2015, 89, 248-258. [CrossRef]

111. Meng, H.; Xue, M.; Xia, T.; Ji, Z.; Tarn, D.Y.; Zink, J.I.; Nel, A.E. Use of size and a copolymer design feature to improve the biodistribution and the enhanced permeability and retention effect of doxorubicin-loaded mesoporous silica nanoparticles in a murine xenograft tumor model. ACS Nano 2011, 5, 4131-4144. [CrossRef] [PubMed]

112. Duo, Y.; Li, Y.; Chen, C.; Liu, B.; Wang, X.; Zeng, X.; Chen, H. DOX-loaded pH-sensitive mesoporous silica nanoparticles coated with PDA and PEG induce pro-death autophagy in breast cancer. RSC Adv. 2017, 7, 39641-39650. [CrossRef]

113. Hatakeyama, H.; Akita, H.; Harashima, H. A multifunctional envelope type nano device (MEND) for gene delivery to tumours based on the EPR effect: A strategy for overcoming the PEG dilemma. Adv. Drug Deliv. Rev. 2011, 63, 152-160. [CrossRef]

114. Gabizon, A.; Szebeni, J. Complement activation: A potential threat on the safety of poly(ethylene glycol)-coated nanomedicines. ACS Nano 2020, 14, 7682-7688. [CrossRef] [PubMed]

115. Kozma, G.T.; Shimizu, T.; Ishida, T.; Szebeni, J. Anti-PEG antibodies: Properties, formation, testing and role in adverse immune reactions to PEGylated nano-biopharmaceuticals. Adv. Drug Deliv. Rev. 2020, 154-155, 163-175. [CrossRef] [PubMed]

116. De Campos, A.M.; Diebold, Y.; Carvalho, E.L.S.; Sánchez, A.; Alonso, M.J. chitosan nanoparticles as new ocular drug delivery systems: In vitro stability, in vivo fate, and cellular toxicity. Pharm. Res. 2004, 21, 803-810. [CrossRef]

117. Oh, K.T.; Lee, E.S.; Kim, D.; Bae, Y.H. 1-Histidine-based pH-sensitive anticancer drug carrier micelle: Reconstitution and brief evaluation of its systemic toxicity. Int. J. Pharm. 2008, 358, 177-183. [CrossRef]

118. Becker, L.C.; Bergfeld, W.F.; Belsito, D.V.; Klaassen, C.D.; Marks, J.G.; Shank, R.C.; Slaga, T.J.; Snyder, P.W.; Panel, C.I.R.E.; Andersen, F.A. Final report of the safety assessment of hyaluronic acid, potassium hyaluronate, and sodium hyaluronate. Int. J. Toxicol. 2009, 28, 5-67. [CrossRef]

119. Pourjavadi, A.; Tehrani, Z.M. Mesoporous Silica Nanoparticles (MCM-41) coated PEGylated chitosan as a pH-responsive nanocarrier for triggered release of erythromycin. Int. J. Polym. Mater. 2014, 63, 692-697. [CrossRef]

120. Liu, W.T.; Yang, Y.; Shen, P.H.; Gao, X.J.; He, S.Q.; Liu, H.; Zhu, C.S. Facile and simple preparation of pH-sensitive chitosanmesoporous silica nanoparticles for future breast cancer treatment. Express Polym. Lett. 2015, 9, 8. [CrossRef]

121. Wu, J.; Jiang, W.; Shen, Y.; Tian, R. Synthesis and characterization of mesoporous magnetic nanocomposites wrapped with chitosan gatekeepers for $\mathrm{pH}$-sensitive controlled release of doxorubicin. Mater. Sci. Eng. C 2017, 70, 132-140. [CrossRef]

122. Niedermayer, S.; Weiss, V.; Herrmann, A.; Schmidt, A.; Datz, S.; Müller, K.; Wagner, E.; Bein, T.; Bräuchle, C. Multifunctional polymer-capped mesoporous silica nanoparticles for $\mathrm{pH}$-responsive targeted drug delivery. Nanoscale 2015, 7, 7953-7964. [CrossRef]

123. Pourjavadi, A.; Tehrani, Z.M.; Bennett, C. PEG-co-Polyvinyl pyridine coated magnetic mesoporous silica nanoparticles for pH-responsive controlled release of doxorubicin. Int. J. Polym. Mater. 2015, 64, 570-577. [CrossRef]

124. Yuan, L.; Tang, Q.; Yang, D.; Zhang, J.Z.; Zhang, F.; Hu, J. Preparation of pH-responsive mesoporous silica nanoparticles and their application in controlled drug delivery. J. Phys. Chem. C 2011, 115, 9926-9932. [CrossRef]

125. Saroj, S.; Rajput, S.J. Tailor-made $\mathrm{pH}$-sensitive polyacrylic acid functionalized mesoporous silica nanoparticles for efficient and controlled delivery of anti-cancer drug Etoposide. Drug Dev. Ind. Pharm. 2018, 44, 1198-1211. [CrossRef]

126. Tian, B.; Liu, S.; Wu, S.; Lu, W.; Wang, D.; Jin, L.; Hu, B.; Li, K.; Wang, Z.; Quan, Z. pH-responsive poly (acrylic acid)-gated mesoporous silica and its application in oral colon targeted drug delivery for doxorubicin. Colloids Surf. B Biointerfaces 2017, 154, 287-296. [CrossRef] 
127. Zhang, Y.; Xu, J. Mesoporous silica nanoparticle-based intelligent drug delivery system for bienzyme-responsive tumour targeting and controlled release. R. Soc. Open Sci. 2018, 5, 170986. [CrossRef] [PubMed]

128. Xu, H.; Wang, Z.; Li, Y.; Guo, Y.; Zhou, H.; Li, Y.; Wu, F.; Zhang, L.; Yang, X.; Lu, B.; et al. Preparation and characterization of a dual-receptor mesoporous silica nanoparticle-hyaluronic acid-RGD peptide targeting drug delivery system. RSC Adv. 2016, 6, 40427-40435. [CrossRef]

129. Fang, Z.; Li, X.; Xu, Z.; Du, F.; Wang, W.; Shi, R.; Gao, D. Hyaluronic acid-modified mesoporous silica-coated superparamagnetic $\mathrm{Fe}_{3} \mathrm{O}_{4}$ nanoparticles for targeted drug delivery. Int. J. Nanomed. 2019, 14, 5785-5797. [CrossRef] [PubMed]

130. Lu, J.; Luo, B.; Chena, Z.; Yuanb, Y.; Kuangc, Y.; Wana, L.; Yaoa, L.; Chena, X.; Jianga, B.; Liub, J.; et al. Host-guest fabrication of dual-responsive hyaluronic acid/mesoporous silica nanoparticle based drug delivery system for targeted cancer therapy. Int. J. Biol. Macromol. 2020, 146, 363-373. [CrossRef] [PubMed]

131. Palanikumar, L.; Kim, J.; Oh, J.Y.; Choi, H.; Park, M.-H.; Kim, C.; Ryu, J.-H. Hyaluronic acid-modified polymeric gatekeepers on biodegradable mesoporous silica nanoparticles for targeted cancer therapy. ACS Biomater. Sci. Eng. 2018, 4, 1716-1722. [CrossRef] [PubMed]

132. Carmona, M.M.; Lozano, D.; Colilla, M.; Regí, M.V. Selective topotecan delivery to cancer cells by targeted pH-sensitive mesoporous silica nanoparticles. RSC Adv. 2016, 6, 50923-50932. [CrossRef]

133. Zou, Z.; He, D.; He, X.; Wang, K.; Yang, X.; Qing, Z.; Zhou, Q. Natural gelatin capped mesoporous silica nanoparticles for intracellular acid-triggered drug delivery. Langmuir 2013, 29, 12804-12810. [CrossRef] [PubMed]

134. Xu, J.-H.; Gao, F.-P.; Li, L.-L.; Ma, H.L.; Fan, Y.-S.; Liu, W.; Guo, S.-S.; Zhao, X.-Z.; Wang, H. Gelatin-mesoporous silica nanoparticles as matrix metalloproteinases-degradable drug delivery systems in vivo. Microporous Mesoporous Mater. 2013, 182, 165-172. [CrossRef]

135. Che, E.; Gao, Y.; Wan, L.; Zhang, Y.; Han, N.; Bai, J.; Li, J.; Sha, Z.; Wang, S. Paclitaxel/gelatin coated magnetic mesoporous silica nanoparticles: Preparation and antitumor efficacy in vivo. Microporous Mesoporous Mater. 2015, 204, 226-234. [CrossRef]

136. Tukappa, A.; Ultimo, A.; De La Torre, C.; Pardo, T.; Sancenón, F.; Martinez-Mañez, R. Polyglutamic acid-gated mesoporous silica nanoparticles for enzyme-controlled drug delivery. Langmuir 2016, 32, 8507-8515. [CrossRef] [PubMed]

137. Li, X.; Xie, C.; Xia, H.; Wang, Z. pH and Ultrasound dual-responsive polydopamine-coated mesoporous silica nanoparticles for controlled drug delivery. Langmuir 2018, 34, 9974-9981. [CrossRef] [PubMed]

138. Lei, W.; Sun, C.; Jiang, T.; Gao, Y.; Yang, Y.; Zhao, Q.; Wang, S. Polydopamine-coated mesoporous silica nanoparticles for multi-responsive drug delivery and combined chemo-photothermal therapy. Mater. Sci. Eng. C 2019, 105, 110103. [CrossRef]

139. Zheng, Q.; Lin, T.; Wu, H.; Guo, L.; Ye, P.; Hao, Y.; Guo, Q.; Jiang, J.; Fu, F.; Chen, G. Mussel-inspired polydopamine coated mesoporous silica nanoparticles as $\mathrm{pH}$-sensitive nanocarriers for controlled release. Int. J. Pharm. 2014, 463, 22-26. [CrossRef]

140. Shi, M.; Zhang, J.; Li, J.; Fan, Y.; Wang, J.; Sun, W.; Yang, H.; Peng, C.; Shen, M.; Shi, X. Polydopamine-coated magnetic mesoporous silica nanoparticles for multimodal cancer theranostics. J. Mater. Chem. B 2019, 7, 368-372. [CrossRef]

141. You, Y.-Z.; Kalebaila, K.K.; Brock, S.L.; Oupický, D. Temperature-Controlled Uptake and Release in PNIPAM-Modified Porous Silica Nanoparticles. Chem. Mater. 2008, 20, 3354-3359. [CrossRef]

142. Yang, Z.; Fan, W.; Zou, J.; Tang, W.; Li, L.; He, L.; Shen, Z.; Wang, Z.; Jacobson, O.; Aronova, M.A.; et al. Precision cancer theranostic platform by in situ polymerization in perylene diimide-hybridized hollow mesoporous organosilica nanoparticles. $J$. Am. Chem. Soc. 2019, 141, 14687-14698. [CrossRef]

143. Shu, Y.; Song, R.; Zheng, A.; Huang, J.; Chen, M.; Wang, J. Thermo/pH dual-stimuli-responsive drug delivery for chemo/photothermal therapy monitored by cell imaging. Talanta 2018, 181, 278-285. [CrossRef]

144. Peralta, M.E.; Jadhav, S.A.; Magnacca, G.; Scalarone, D.; Mártire, D.O.; Parolo, M.E.; Carlos, L. Synthesis and in vitro testing of thermoresponsive polymer-grafted core-shell magnetic mesoporous silica nanoparticles for efficient controlled and targeted drug delivery. J. Colloid Interface Sci. 2019, 544, 198-205. [CrossRef] [PubMed]

145. Heiden, M.G.V.; Cantley, L.C.; Thompson, C.B. Understanding the Warburg effect: The metabolic requirements of cell proliferation. Science 2009, 324, 1029-1033. [CrossRef]

146. Anderson, M.; Moshnikova, A.; Engelman, D.M.; Reshetnyak, Y.K.; Andreev, O.A. Probe for the measurement of cell surface pH in vivo and ex vivo. Proc. Natl. Acad. Sci. USA 2016, 113, 8177-8181. [CrossRef]

147. Gisbert-Garzarán, M.; Manzano, M.; Vallet-Regí, M. pH-responsive mesoporous silica and carbon nanoparticles for drug delivery. Bioengineering 2017, 4, 3. [CrossRef] [PubMed]

148. Lim, C.; Lee, D.W.; Israelachvili, J.N.; Jho, Y.; Hwang, D.S. Contact time- and pH-dependent adhesion and cohesion of low molecular weight chitosan coated surfaces. Carbohydr. Polym. 2015, 117, 887-894. [CrossRef]

149. Pourjavadi, A.; Tehrani, Z.M.; Jokar, S. Chitosan based supramolecular polypseudorotaxane as a pH-responsive polymer and their hybridization with mesoporous silica-coated magnetic graphene oxide for triggered anticancer drug delivery. Polymers 2015, 76, 52-61. [CrossRef]

150. Liu, J.; Luo, Z.; Zhang, J.; Luo, T.; Zhou, J.; Zhao, X.; Cai, K. Hollow mesoporous silica nanoparticles facilitated drug delivery via cascade $\mathrm{pH}$ stimuli in tumor microenvironment for tumor therapy. Biomaterials 2016, 83, 51-65. [CrossRef]

151. Yang, Y.; Achazi, K.; Jia, Y.; Wei, Q.; Haag, R.; Li, J. Complex assembly of polymer conjugated mesoporous silica nanoparticles for intracellular pH-responsive drug delivery. Langmuir 2016, 32, 12453-12460. [CrossRef] 
152. Peng, S.; Yuan, X.; Lin, W.; Cai, C.; Zhang, L. pH-responsive controlled release of mesoporous silica nanoparticles capped with Schiff base copolymer gatekeepers: Experiment and molecular dynamics simulation. Colloids Surf. B Biointerfaces 2019, 176, 394-403. [CrossRef]

153. Talavera-Pech, W.A.; Esparza-Ruiz, A.; Quintana-Owen, P.; Vilchis-Néstor, A.R.; Barrón-Zambrano, J.A.; Ávila-Ortega, A. Synthesis of $\mathrm{pH}$-sensitive poly( $\beta$-amino ester)-coated mesoporous silica nanoparticles for the controlled release of drugs. Appl. Nanosci. 2018, 8, 853-866. [CrossRef]

154. Fernando, I.R.; Ferris, D.P.; Frasconi, M.; Malin, D.; Strekalova, E.; Yilmaz, M.D.; Ambrogio, M.W.; Algaradah, M.M.; Hong, M.P.; Chen, X.; et al. Esterase- and pH-responsive poly( $\beta$-amino ester)-capped mesoporous silica nanoparticles for drug delivery. Nanoscale 2015, 7, 7178-7183. [CrossRef]

155. Llinàs, M.C.; Martínez-Edo, G.; Cascante, A.; Porcar, I.; Borrós, S.; Sánchez-García, D. Preparation of a mesoporous silica-based nano-vehicle for dual DOX/CPT pH-triggered delivery. Drug Deliv. 2018, 25, 1137-1146. [CrossRef]

156. Tarn, D.; Xue, M.; Zink, J.I. pH-responsive dual cargo delivery from mesoporous silica nanoparticles with a metal-latched nanogate. Inorg. Chem. 2013, 52, 2044-2049. [CrossRef] [PubMed]

157. Wang, W.; Wang, Y.; Wang, Y.; Gong, H.; Zhu, H.; Liu, M. Redox/pH dual stimuli-responsive ZnO QDs-gated mesoporous silica nanoparticles as carriers in cancer therapy. IET Nanobiotechnol. 2019, 13, 640-649. [CrossRef]

158. Wu, S.; Huang, X.; Du, X. pH- and redox-triggered synergistic controlled release of a ZnO-gated hollow mesoporous silica drug delivery system. J. Mater. Chem. B 2014, 3, 1426-1432. [CrossRef] [PubMed]

159. Moreira, A.F.; Gaspar, V.M.; Costa, E.C.; de Melo-Diogo, D.; Machado, P.; Paquete, C.M.; Correia, I.J. Preparation of end-capped pH-sensitive mesoporous silica nanocarriers for on-demand drug delivery. Eur. J. Pharm. Biopharm. 2014, 88, 1012-1025. [CrossRef]

160. Baig, M.H.; Adil, M.; Khan, R.; Dhadi, S.; Ahmad, K.; Rabbani, G.; Bashir, T.; Imran, M.A.; Husain, F.M.; Lee, E.J.; et al. Enzyme targeting strategies for prevention and treatment of cancer: Implications for cancer therapy. Semin. Cancer Biol. 2019, 56, 1-11. [CrossRef] [PubMed]

161. Jung, H. Hyaluronidase: An overview of its properties, applications, and side effects. Arch. Plast. Surg. 2020, 47, 297-300. [CrossRef]

162. Senbanjo, L.T.; Chellaiah, M.A. CD44: A multifunctional cell surface adhesion receptor is a regulator of progression and metastasis of cancer cells. Front. Cell Dev. Biol. 2017, 5, 18. [CrossRef]

163. Gamcsik, M.P.; Kasibhatla, M.S.; Teeter, S.D.; Colvin, O.M. Glutathione levels in human tumors. Biomarkers 2012, 17, 671-691. [CrossRef]

164. Palanikumar, L.; Choi, E.S.; Cheon, J.Y.; Joo, S.H.; Ryu, J.-H. Noncovalent polymer-gatekeeper in mesoporous silica nanoparticles as a targeted drug delivery platform. Adv. Funct. Mater. 2014, 25, 957-965. [CrossRef]

165. Lee, J.; Oh, E.-T.; Han, Y.; Kim, H.G.; Park, H.J.; Kim, C. Mesoporous silica nanocarriers with cyclic peptide gatekeeper: Specific targeting of aminopeptidase $\mathrm{n}$ and triggered drug release by stimuli-responsive conformational transformation. Chem. A Eur. J. 2017, 23, 16966-16971. [CrossRef] [PubMed]

166. Li, Z.-Y.; Hu, J.-J.; Xu, Q.; Chen, S.; Jia, H.-Z.; Sun, Y.-X.; Zhuo, R.-X.; Zhang, X.-Z. A redox-responsive drug delivery system based on RGD containing peptide-capped mesoporous silica nanoparticles. J. Mater. Chem. B 2014, 3, 39-44. [CrossRef] [PubMed]

167. Chen, X.; Sun, H.; Hu, J.; Han, X.; Liu, H.; Hu, Y. Transferrin gated mesoporous silica nanoparticles for redox-responsive and targeted drug delivery. Colloids Surf. B Biointerfaces 2017, 152, 77-84. [CrossRef]

168. Cui, Y.; Dong, H.; Cai, X.; Wang, D.; Li, Y. Mesoporous silica nanoparticles capped with disulfide-linked PEG gatekeepers for glutathione-mediated controlled release. ACS Appl. Mater. Interfaces 2012, 4, 3177-3183. [CrossRef]

169. Zhu, C.-L.; Lu, C.-H.; Song, X.-Y.; Yang, H.-H.; Wang, X.-R. Bioresponsive controlled release using mesoporous silica nanoparticles capped with aptamer-based molecular gate. J. Am. Chem. Soc. 2011, 133, 1278-1281. [CrossRef] [PubMed]

170. Baliś, A.; Wolski, K.; Zapotoczny, S. Thermoresponsive polymer gating system on mesoporous shells of silica particles serving as smart nanocontainers. Polymers 2020, 12, 888. [CrossRef]

171. Paris, J.L.; Cabañas, M.V.; Manzano, M.; Vallet-Regí, M. Polymer-grafted mesoporous silica nanoparticles as ultrasound-responsive drug carriers. ACS Nano 2015, 9, 11023-11033. [CrossRef] [PubMed]

172. Cheng, C.-A.; Chen, W.; Zhang, L.; Wu, H.H.; Zink, J.I. A responsive mesoporous silica nanoparticle platform for magnetic resonance imaging-guided high-intensity focused ultrasound-stimulated cargo delivery with controllable location, time, and dose. J. Am. Chem. Soc. 2019, 141, 17670-17684. [CrossRef] [PubMed]

173. Manzano, M.; Vallet-Regí, M. Ultrasound responsive mesoporous silica nanoparticles for biomedical applications. Chem. Commun. 2019, 55, 2731-2740. [CrossRef]

174. Li, X.; Wang, Z.; Xia, H. Ultrasound reversible response nanocarrier based on sodium alginate modified mesoporous silica nanoparticles. Front. Chem. 2019, 7, 59. [CrossRef]

175. Wang, Y.; Wang, L.; Guo, L.; Yan, M.; Feng, L.; Dong, S.; Hao, J. Photo-responsive magnetic mesoporous silica nanocomposites for magnetic targeted cancer therapy. New J. Chem. 2019, 43, 4908-4918. [CrossRef]

176. Tang, Y.; Hu, H.; Zhang, M.G.; Song, J.; Nie, L.; Wang, S.; Niu, G.; Huang, P.; Lu, G.; Chen, X. An aptamer-targeting photoresponsive drug delivery system using "off-on" graphene oxide wrapped mesoporous silica nanoparticles. Nanoscale 2015, 7, 6304-6310. [CrossRef] 
177. Seth, A.; Derami, H.G.; Gupta, P.; Wang, Z.; Rathi, P.; Gupta, R.; Cao, T.; Morrissey, J.J.; Singamaneni, S. PolydopamineMesoporous silica core-Shell nanoparticles for combined photothermal immunotherapy. ACS Appl. Mater. Interfaces 2020, 12, 42499-42510. [CrossRef]

178. Golombek, S.K.; May, J.-N.; Theek, B.; Appold, L.; Drude, N.; Kiessling, F.; Lammers, T. Tumor targeting via EPR: Strategies to enhance patient responses. Adv. Drug Deliv. Rev. 2018, 130, 17-38. [CrossRef] [PubMed]

179. Yoo, J.; Park, C.; Yi, G.; Lee, D.; Koo, H. Active targeting strategies using biological ligands for nanoparticle drug delivery systems. Cancers 2019, 11, 640. [CrossRef]

180. Price, P.M.; Mahmoud, W.E.; Al-Ghamdi, A.A.; Bronstein, L.M. Magnetic drug delivery: Where the field is going. Front. Chem. 2018, 6, 619. [CrossRef]

181. Oltolina, F.; Colangelo, D.; Miletto, I.; Clemente, N.; Miola, M.; Verné, E.; Prat, M.; Follenzi, A. Prat tumor targeting by monoclonal antibody functionalized magnetic nanoparticles. Nanomaterials 2019, 9, 1575. [CrossRef]

182. Torchilin, V. Tumor delivery of macromolecular drugs based on the EPR effect. Adv. Drug Deliv. Rev. 2011, 63, 131-135. [CrossRef]

183. Matsumura, Y.; Maeda, H. A new concept for macromolecular therapeutics in cancer chemotherapy: Mechanism of tumor-itropic accumulation of proteins and the antitumor agent smancs. Cancer Res. 1986, 46, 6387-6392. [PubMed]

184. Tarn, D.; Ashley, C.E.; Xue, M.; Carnes, E.C.; Zink, J.I.; Brinker, C.J. Mesoporous silica nanoparticle nanocarriers: Biofunctionality and biocompatibility. Acc. Chem. Res. 2013, 46, 792-801. [CrossRef] [PubMed]

185. Huynh, E.; Zheng, G. Cancer nanomedicine: Addressing the dark side of the enhanced permeability and retention effect. Nanomedicine 2015, 10, 1993-1995. [CrossRef] [PubMed]

186. Stirland, D.L.; Nichols, J.W.; Miura, S.; Bae, Y.H. Mind the gap: A survey of how cancer drug carriers are susceptible to the gap between research and practice. J. Control. Release 2013, 172, 1045-1064. [CrossRef]

187. Prabhakar, U.; Maeda, H.; Jain, R.K.; Sevick-Muraca, E.M.; Zamboni, W.; Farokhzad, O.C.; Barry, S.T.; Gabizon, A.; Grodzinski, P.; Blakey, D.C. Challenges and key considerations of the enhanced permeability and retention effect for nanomedicine drug delivery in oncology. Cancer Res. 2013, 73, 2412-2417. [CrossRef]

188. Nichols, J.W.; Bae, Y.H. EPR: Evidence and fallacy. J. Control. Release 2014, 190, 451-464. [CrossRef]

189. Gessner, I.; Klimpel, A.; Klußmann, M.; Neundorf, I.; Mathur, S. Interdependence of charge and secondary structure on cellular uptake of cell penetrating peptide functionalized silica nanoparticles. Nanoscale Adv. 2019, 2, 453-462. [CrossRef]

190. Tsai, C.-P.; Chen, C.-Y.; Hung, Y.; Chang, F.-H.; Mou, C.-Y. Monoclonal antibody-functionalized mesoporous silica nanoparticles (MSN) for selective targeting breast cancer cells. J. Mater. Chem. 2009, 19, 5737-5743. [CrossRef]

191. Gao, Y.; Gu, S.; Zhang, Y.; Xie, X.; Yu, T.; Lu, Y.; Zhu, Y.; Chen, W.; Zhang, H.; Dong, H.; et al. The architecture and function of monoclonal antibody-functionalized mesoporous silica nanoparticles loaded with mifepristone: Repurposing abortifacient for cancer metastatic chemoprevention. Small 2016, 12, 2595-2608. [CrossRef] [PubMed]

192. Mandal, T.; Beck, M.; Kirsten, N.; Lindén, M.; Buske, C. Targeting murine leukemic stem cells by antibody functionalized mesoporous silica nanoparticles. Sci. Rep. 2018, 8, 989. [CrossRef]

193. Rivero-Buceta, E.; Vidaurre-Agut, C.; Vera-Donoso, C.D.; Benlloch, J.M.; Moreno-Manzano, V.; Botella, P. PSMA-targeted mesoporous silica nanoparticles for selective intracellular delivery of docetaxel in prostate cancer cells. ACS Omega 2019, 4, 1281-1291. [CrossRef]

194. Qu, W.; Meng, B.; Yu, Y.; Wang, S. EpCAM antibody-conjugated mesoporous silica nanoparticles to enhance the anticancer efficacy of carboplatin in retinoblastoma. Mater. Sci. Eng. C 2017, 76, 646-651. [CrossRef]

195. Zhang, Y.; Guo, J.; Zhang, X.-L.; Li, D.-P.; Zhang, T.-T.; Gao, F.-F.; Liu, N.-F.; Sheng, X.-G. Antibody fragment-armed mesoporous silica nanoparticles for the targeted delivery of bevacizumab in ovarian cancer cells. Int. J. Pharm. 2015, 496, 1026-1033. [CrossRef]

196. Chen, F.; Ma, K.; Madajewski, B.; Zhuang, L.; Rickert, K.; Marelli, M.; Yoo, B.; Turker, M.Z.; Overholtzer, M.; Quinn, T.P.; et al Ultrasmall targeted nanoparticles with engineered antibody fragments for imaging detection of HER2-overexpressing breast cancer. Nat. Commun. 2018, 9, 1-11. [CrossRef] [PubMed]

197. Cui, Y.; Xu, Q.; Chow, P.K.-H.; Wang, D.; Wang, C.-H. Transferrin-conjugated magnetic silica PLGA nanoparticles loaded with doxorubicin and paclitaxel for brain glioma treatment. Biomaterials 2013, 34, 8511-8520. [CrossRef]

198. Saini, K.; Bandyopadhyaya, R. Transferrin-conjugated polymer-coated mesoporous silica nanoparticles loaded with gemcitabine for killing pancreatic cancer cells. ACS Appl. Nano Mater. 2020, 3, 229-240. [CrossRef]

199. Hao, W.; Shen, Y.; Zhang, J.; Liu, D.; Shang, Y.; Xu, S. Dual-pH-sensitivity and tumour targeting core-shell particles for intracellular drug delivery. RSC Adv. 2017, 7, 851-860. [CrossRef]

200. Lu, N.; Tian, Y.; Tian, W.; Huang, P.; Liu, Y.; Tang, Y.; Wang, C.; Wang, S.; Su, Y.; Zhang, Y.; et al. Smart cancer cell targeting imaging and drug delivery system by systematically engineering periodic mesoporous organosilica nanoparticles. ACS Appl. Mater. Interfaces 2016, 8, 2985-2993. [CrossRef]

201. Silvestri, B.; Pezzella, A.; Luciani, G.; Costantini, A.; Tescione, F.; Branda, F. Heparin conjugated silica nanoparticle synthesis. Mater. Sci. Eng. C 2012, 32, 2037-2041. [CrossRef]

202. Yan, H.; You, Y.; Li, X.; Liu, L.; Guo, F.; Zhang, Q.; Liu, D.; Tong, Y.; Ding, S.; Wang, J. Preparation of RGD peptide/folate acid double-targeted mesoporous silica nanoparticles and its application in human breast cancer MCF-7 cells. Front. Pharmacol. 2020, 11, 898. [CrossRef]

203. Pan, L.; He, Q.; Liu, J.; Chen, Y.; Ma, M.; Zhang, L.; Shi, J. Nuclear-targeted drug delivery of TAT peptide-conjugated monodisperse mesoporous silica nanoparticles. J. Am. Chem. Soc. 2012, 134, 5722-5725. [CrossRef] 
204. Li, J.; Liu, F.; Shao, Q.; Min, Y.; Costa, M.; Yeow, E.K.L.; Xing, B. Enzyme-responsive cell-penetrating peptide conjugated mesoporous silica quantum dot nanocarriers for controlled release of nucleus-targeted drug molecules and real-time intracellular fluorescence imaging of tumor cells. Adv. Healthc. Mater. 2014, 3, 1230-1239. [CrossRef]

205. Thapa, R.K.; Nguyen, H.T.; Gautam, M.; Shrestha, A.; Lee, E.S.; Ku, S.K.; Choi, H.-G.; Yong, C.S.; Kim, J.O. Hydrophobic binding peptide-conjugated hybrid lipid-mesoporous silica nanoparticles for effective chemo-photothermal therapy of pancreatic cancer. Drug Deliv. 2017, 24, 1690-1702. [CrossRef] [PubMed]

206. Mao, Y.; Feng, S.; Zhang, X.; Zhao, Q.; Fang, Y.; Wang, S.; Yu, F. Thiolated polymer and Cell-Penetrating Peptide dual-surface functionalization of mesoporous silicon nanoparticles to overcome intestinal barriers. J. Drug Deliv. Sci. Technol. 2019, 53, 101184. [CrossRef]

207. Tan, X.; Zhang, Y.; Wang, Q.; Ren, T.; Gou, J.; Guo, W.; Yin, T.; He, H.; Zhang, Y.; Tang, X. Cell-penetrating peptide together with PEG-modified mesostructured silica nanoparticles promotes mucous permeation and oral delivery of therapeutic proteins and peptides. Biomater. Sci. 2019, 7, 2934-2950. [CrossRef] [PubMed]

208. Gessner, I.; Neundorf, I. Nanoparticles modified with cell-penetrating peptides: Conjugation mechanisms, physicochemical properties, and application in cancer diagnosis and therapy. Int. J. Mol. Sci. 2020, 21, 2536. [CrossRef] [PubMed]

209. Vares, G.; Jallet, V.; Matsumoto, Y.; Rentier, C.; Takayama, K.; Sasaki, T.; Hayashi, Y.; Kumada, H.; Sugawara, H. Functionalized mesoporous silica nanoparticles for innovative boron-neutron capture therapy of resistant cancers. Nanomed. Nanotechnol. Biol. Med. 2020, 27, 102195. [CrossRef] [PubMed]

210. Li, L.-L.; Yin, Q.; Cheng, J.; Lu, Y. Polyvalent mesoporous silica nanoparticle-aptamer bioconjugates target breast cancer cells. Adv. Healthc. Mater. 2012, 1, 567-572. [CrossRef] [PubMed]

211. Pascual, L.; Cerqueira-Coutinho, C.; García-Fernández, A.; de Luis, B.; Bernardes, E.S.; Albernaz, M.S.; Missailidis, S.; MartínezMáñez, R.; Santos-Oliveira, R.; Orzaez, M.; et al. MUC1 aptamer-capped mesoporous silica nanoparticles for controlled drug delivery and radio-imaging applications. Nanomed. Nanotechnol. Biol. Med. 2017, 13, 2495-2505. [CrossRef]

212. Shen, Y.; Li, M.; Liu, T.; Liu, J.; Xie, Y.; Zhang, J.; Xu, S.; Liu, H. A dual-functional HER2 aptamer-conjugated, pH-activated mesoporous silica nanocarrier-based drug delivery system provides in vitro synergistic cytotoxicity in HER2-positive breast cancer cells. Int. J. Nanomed. 2019, 14, 4029-4044. [CrossRef]

213. Yang, Y.; Zhao, W.; Tan, W.; Lai, Z.; Fang, D.; Jiang, L.; Zuo, C.; Yang, N.; Lai, Y. An efficient cell-targeting drug delivery system based on aptamer-modified mesoporous silica nanoparticles. Nanoscale Res. Lett. 2019, 14, 1-10. [CrossRef] [PubMed]

214. Siminzar, P.; Omidi, Y.; Golchin, A.; Aghanejad, A.; Barar, J. Targeted delivery of doxorubicin by magnetic mesoporous silica nanoparticles armed with mucin-1 aptamer. J. Drug Target. 2019, 28, 92-101. [CrossRef]

215. Saroj, S.; Rajput, S.J. Etoposide encased folic acid adorned mesoporous silica nanoparticles as potent nanovehicles for enhanced prostate cancer therapy: Synthesis, characterization, cellular uptake and biodistribution. Artif. Cells Nanomed. Biotechnol. 2018, 46, S1115-S1130. [CrossRef] [PubMed]

216. Xu, X.; Wu, C.; Bai, A.; Liu, X.; Lv, H.; Liu, Y. Folate-functionalized mesoporous silica nanoparticles as a liver tumor-targeted drug delivery system to improve the antitumor effect of paclitaxel. J. Nanomater. 2017, 2017, 1-13. [CrossRef]

217. AbouAitah, K.; Swiderska-Sroda, A.; Farghali, A.A.; Wojnarowicz, J.; Stefanek, A.; Gierlotka, S.; Opalinska, A.; Allayeh, A.K.; Ciach, T.; Lojkowski, W. Folic acid-conjugated mesoporous silica particles as nanocarriers of natural prodrugs for cancer targeting and antioxidant action. Oncotarget 2018, 9, 26466-26490. [CrossRef]

218. Khosraviyan, P.; Ardestani, M.S.; Khoobi, M.; Ostad, S.N.; Dorkoosh, F.A.; Javar, H.A.; Amanlou, M. Mesoporous silica nanoparticles functionalized with folic acid/methionine for active targeted delivery of docetaxel. Onco Targets Ther. 2016, 9 , 7315-7330. [CrossRef] [PubMed]

219. Qu, W.; Meng, B.; Yu, Y.; Wang, S. Folic acid-conjugated mesoporous silica nanoparticles for enhanced therapeutic efficacy of topotecan in retina cancers. Int. J. Nanomed. 2018, 13, 4379-4389. [CrossRef]

220. Mishra, S.; Manna, K.; Kayal, U.; Saha, M.; Chatterjee, S.; Chandra, D.; Hara, M.; Datta, S.; Bhaumik, A.; Das Saha, K. Folic acid-conjugated magnetic mesoporous silica nanoparticles loaded with quercetin: A theranostic approach for cancer management. RSC Adv. 2020, 10, 23148-23164. [CrossRef]

221. Huang, Y.-Q.; Sun, L.-J.; Zhang, R.; Hu, J.; Liu, X.-F.; Jiang, R.-C.; Fan, Q.-L.; Wang, L.-H.; Huang, W. Hyaluronic acid nanoparticles based on a conjugated oligomer photosensitizer: Target-specific two-photon imaging, redox-sensitive drug delivery, and synergistic chemo-photodynamic therapy. ACS Appl. Bio Mater. 2019, 2, 2421-2434. [CrossRef]

222. Scott, A.M.; Allison, J.P.; Wolchok, J.D. Monoclonal antibodies in cancer therapy. Cancer Immun. 2012, 12, 14.

223. Shepard, H.M.; Phillips, G.L.; Thanos, C.D.; Feldmann, M. Developments in therapy with monoclonal antibodies and related proteins. Clin. Med. 2017, 17, 220-232. [CrossRef]

224. Cruz, E.; Kayser, V. Monoclonal antibody therapy of solid tumors: Clinical limitations and novel strategies to enhance treatment efficacy. Biol. Targets Ther. 2019, 13, 33-51. [CrossRef] [PubMed]

225. Chiu, M.L.; Goulet, D.R.; Teplyakov, A.; Gilliland, G.L. Antibody structure and function: The basis for engineering therapeutics. Antibodies 2019, 8, 55. [CrossRef] [PubMed]

226. Tiller, K.E.; Tessier, P.M. Advances in antibody design. Annu. Rev. Biomed. Eng. 2015, 17, 191-216. [CrossRef]

227. Thurber, G.M.; Schmidt, M.M.; Wittrup, K.D. Antibody tumor penetration: Transport opposed by systemic and antigen-mediated clearance. Adv. Drug Deliv. Rev. 2008, 60, 1421-1434. [CrossRef] 
228. Kamaly, N.; Xiao, Z.; Valencia, P.M.; Radovic-Moreno, A.F.; Farokhzad, O.C. Targeted polymeric therapeutic nanoparticles: Design, development and clinical translation. Chem. Soc. Rev. 2012, 41, 2971-3010. [CrossRef] [PubMed]

229. Lazarovits, J.; Chen, Y.Y.; Sykes, E.A.; Chan, W.C.W. Nanoparticle-blood interactions: The implications on solid tumour targeting. Chem. Commun. 2015, 51, 2756-2767. [CrossRef]

230. Marques, A.C.; Costa, P.J.; Velho, S.; Amaral, M.H. Functionalizing nanoparticles with cancer-targeting antibodies: A comparison of strategies. J. Control. Release 2020, 320, 180-200. [CrossRef] [PubMed]

231. Nelson, A.L. Antibody fragments. $m A$ bs 2010, 2, 77-83. [CrossRef]

232. Cheng, W.W.; Allen, T.M. Targeted delivery of anti-CD19 liposomal doxorubicin in B-cell lymphoma: A comparison of whole monoclonal antibody, Fab' fragments and single chain Fv. J. Control. Release 2008, 126, 50-58. [CrossRef]

233. Richards, D.A.; Maruani, A.; Chudasama, V. Antibody fragments as nanoparticle targeting ligands: A step in the right direction. Chem. Sci. 2017, 8, 63-77. [CrossRef]

234. Böttger, R.; Hoffmann, R.; Knappe, D. Differential stability of therapeutic peptides with different proteolytic cleavage sites in blood, plasma and serum. PLoS ONE 2017, 12, e0178943. [CrossRef]

235. Zapadka, K.L.; Becher, F.J.; Dos Santos, A.L.G.; Jackson, S.E. Factors affecting the physical stability (aggregation) of peptide therapeutics. Interface Focus 2017, 7, 20170030. [CrossRef]

236. Boturyn, D.; Dumy, P. Tumor targeting with RGD peptide ligands-design of new molecular conjugates for imaging and therapy of cancers. Anti-Cancer Agents Med. Chem. 2007, 7, 552-558. [CrossRef]

237. Chakravarty, R.; Chakraborty, S.; Dash, A. Molecular imaging of breast cancer: Role of RGD peptides. Mini-Reviews Med. Chem. 2015, 15, 1073-1094. [CrossRef] [PubMed]

238. Nieberler, M.; Reuning, U.; Reichart, F.; Notni, J.; Wester, H.-J.; Schwaiger, M.; Weinmüller, M.; Räder, A.; Steiger, K.; Kessler, H. Exploring the role of RGD-recognizing integrins in cancer. Cancers 2017, 9, 116. [CrossRef] [PubMed]

239. Chen, K.; Chen, X. Integrin targeted delivery of chemotherapeutics. Theranostics 2011, 1, 189-200. [CrossRef]

240. Liu, Z.; Wang, F.; Chen, X. Integrin targeted delivery of radiotherapeutics. Theranostics 2011, 1, 201-210. [CrossRef] [PubMed]

241. Desgrosellier, J.S.; Cheresh, D.A. Integrins in cancer: Biological implications and therapeutic opportunities. Nat. Rev. Cancer 2010, 10, 9-22. [CrossRef] [PubMed]

242. Hu, H.; Arena, F.; Gianolio, E.; Boffa, C.; Di Gregorio, E.; Stefania, R.; Orio, L.; Baroni, S.; Aime, S. Mesoporous silica nanoparticles functionalized with fluorescent and MRI reporters for the visualization of murine tumors overexpressing $\alpha \mathrm{v} \beta 3$ receptors. Nanoscale 2016, 8, 7094-7104. [CrossRef]

243. Wu, X.; Han, Z.; Schur, R.M.; Lu, Z.-R. Targeted mesoporous silica nanoparticles delivering arsenic trioxide with environment sensitive drug release for effective treatment of triple negative breast cancer. ACS Biomater. Sci. Eng. 2016, 2, 501-507. [CrossRef] [PubMed]

244. Zhou, H.; Xu, H.; Li, X.; Lv, Y.; Ma, T.; Guo, S.; Huang, Z.; Wang, X.; Xu, P. Dual targeting hyaluronic acid-RGD mesoporous silica coated gold nanorods for chemo-photothermal cancer therapy. Mater. Sci. Eng. C 2017, 81, 261-270. [CrossRef] [PubMed]

245. Zhao, N.; Yang, Z.; Li, B.; Meng, J.; Shi, Z.; Li, P.; Fu, S. RGD-conjugated mesoporous silica-encapsulated gold nanorods enhance the sensitization of triple-negative breast cancer to megavoltage radiation therapy. Int. J. Nanomed. 2016, 11, 5595-5610. [CrossRef]

246. Chen, L.Q.; Pagel, M.D. Evaluating pH in the extracellular tumor microenvironment using CEST MRI and other imaging methods. Adv. Radiol. 2015, 2015, 1-25. [CrossRef]

247. Warburg, O.; Wind, F.; Negelein, E. The metabolism of tumors in the body. J. Gen. Physiol. 1927, 8, 519-530. [CrossRef]

248. Rajamäki, K.; Nordström, T.; Nurmi, K.; Åkerman, K.E.; Kovanen, P.T.; Öörni, K.; Eklund, K.K. Extracellular acidosis is a novel danger signal alerting innate immunity via the NLRP3 inflammasome. J. Biol. Chem. 2013, 288, 13410-13419. [CrossRef]

249. Weerakkody, D.; Moshnikova, A.; Thakur, M.S.; Moshnikova, V.; Daniels, J.; Engelman, D.M.; Andreev, O.A.; Reshetnyak, Y.K. Family of $\mathrm{pH}$ (low) insertion peptides for tumor targeting. Proc. Natl. Acad. Sci. USA 2013, 110, 5834-5839. [CrossRef]

250. Wyatt, L.C.; Moshnikova, A.; Crawford, T.; Engelman, D.M.; Andreev, O.A.; Reshetnyak, Y.K. Peptides of pHLIP family for targeted intracellular and extracellular delivery of cargo molecules to tumors. Proc. Natl. Acad. Sci. USA 2018, 115, E2811-E2818. [CrossRef] [PubMed]

251. Kimbrough, C.W.; Khanal, A.; Zeiderman, M.; Khanal, B.R.; Burton, N.C.; McMasters, K.M.; Vickers, S.M.; Grizzle, W.E.; McNally, L.R. targeting acidity in pancreatic adenocarcinoma: Multispectral optoacoustic tomography detects pH-low insertion peptide probes in vivo. Clin. Cancer Res. 2015, 21, 4576-4585. [CrossRef]

252. Deacon, J.C.; Engelman, N.M.; Barrera, F.N. Targeting acidity in diseased tissues: Mechanism and applications of the membraneinserting peptide, pHLIP. Arch. Biochem. Biophys. 2015, 565, 40-48. [CrossRef] [PubMed]

253. Davies, A.; Lewis, D.J.; Watson, S.P.; Thomas, S.G.; Pikramenou, Z. pH-controlled delivery of luminescent europium coated nanoparticles into platelets. Proc. Natl. Acad. Sci. USA 2012, 109, 1862-1867. [CrossRef] [PubMed]

254. Yu, M.; Guo, F.; Wang, J.; Tan, F.; Li, N. Photosensitizer-loaded pH-responsive hollow gold nanospheres for single light-induced photothermal/photodynamic therapy. ACS Appl. Mater. Interfaces 2015, 7, 17592-17597. [CrossRef] [PubMed]

255. Zhang, Y.; Dang, M.; Tian, Y.; Zhu, Y.; Liu, W.; Tian, W.; Su, Y.; Ni, Q.; Xu, C.; Lu, N.; et al. Tumor acidic microenvironment targeted drug delivery based on pHLIP-modified mesoporous organosilica nanoparticles. ACS Appl. Mater. Interfaces 2017, 9 , 30543-30552. [CrossRef]

256. Trabulo, S.; Cardoso, A.L.; Mano, M.; De Lima, M.C.P. Cell-penetrating peptides-Mechanisms of cellular uptake and generation of delivery systems. Pharmaceuticals 2010, 3, 961-993. [CrossRef] [PubMed] 
257. Madani, F.; Lindberg, S.; Langel, Ü.; Futaki, S.; Gräslund, A. Mechanisms of cellular uptake of cell-penetrating peptides. J. Biophys. 2011, 2011, 1-10. [CrossRef] [PubMed]

258. Farkhani, S.M.; Valizadeh, A.; Karami, H.; Mohammadi, S.; Sohrabi, N.; Badrzadeh, F. Cell penetrating peptides: Efficient vectors for delivery of nanoparticles, nanocarriers, therapeutic and diagnostic molecules. Peptides 2014, 57, 78-94. [CrossRef]

259. Friedman, S.E.C.A.R.L.A.D.; Claypool, S.; Liu, R. The smart targeting of nanoparticles. Curr. Pharm. Des. 2013, 19, 6315-6329. [CrossRef]

260. Jo, H.; Ban, C. Aptamer-nanoparticle complexes as powerful diagnostic and therapeutic tools. Exp. Mol. Med. 2016, 48, e230. [CrossRef]

261. Vandghanooni, S.; Barar, J.; Eskandani, M.; Omidi, Y. Aptamer-conjugated mesoporous silica nanoparticles for simultaneous imaging and therapy of cancer. TrAC Trends Anal. Chem. 2020, 123, 115759. [CrossRef]

262. Lakhin, A.V.; Tarantul, V.Z.; Gening, L.V. Aptamers: Problems, solutions and prospects. Acta Naturae 2013, 5, 34-43. [CrossRef]

263. Zheng, Y.; Gao, Y. Molecular targeted nanotheranostics for future individualized cancer treatment. Expert Opin. Drug Deliv. 2020, 17, 1059-1062. [CrossRef]

264. Nairi, V.; Magnolia, S.; Piludu, M.; Nieddu, M.; Caria, C.A.; Sogos, V.; Vallet-Regì, M.; Monduzzi, M.; Salis, A. Mesoporous silica nanoparticles functionalized with hyaluronic acid. Effect of the biopolymer chain length on cell internalization. Colloids Surf. B Biointerfaces 2018, 168, 50-59. [CrossRef] [PubMed]

265. Yu, X.; Zhu, Y. Preparation of magnetic mesoporous silica nanoparticles as a multifunctional platform for potential drug delivery and hyperthermia. Sci. Technol. Adv. Mater. 2016, 17, 229-238. [CrossRef] [PubMed]

266. Liu, J.; Liu, W.; Zhang, K.; Shi, J.; Zhang, Z. A magnetic drug delivery system with "off-on" state via specific molecular recognition and conformational changes for precise tumor therapy. Adv. Healthc. Mater. 2019, 9, e1901316. [CrossRef] [PubMed]

267. Guisasola, E.; Asín, L.; Beola, L.; De La Fuente, J.M.; Baeza, A.; Vallet-Regí, M. Beyond traditional hyperthermia: In vivo cancer treatment with magnetic-responsive mesoporous silica nanocarriers. ACS Appl. Mater. Interfaces 2017, 10, 12518-12525. [CrossRef] [PubMed]

268. Voronin, D.V.; Sindeeva, O.A.; Kurochkin, M.A.; Mayorova, O.; Fedosov, I.V.; Semyachkina-Glushkovskaya, O.; Gorin, D.A.; Tuchin, V.V.; Sukhorukov, G.B. In vitro and in vivo visualization and trapping of fluorescent magnetic microcapsules in a bloodstream. ACS Appl. Mater. Interfaces 2017, 9, 6885-6893. [CrossRef] [PubMed]

269. Shamsi, M.; Sedaghatkish, A.; Dejam, M.; Saghafian, M.; Mohammadi, M.; Sanati-Nezhad, A. Magnetically assisted intraperitoneal drug delivery for cancer chemotherapy. Drug Deliv. 2018, 25, 846-861. [CrossRef]

270. Ge, J.; Zhang, Y.; Dong, Z.; Jia, J.; Zhu, J.; Miao, X.; Yan, B. Initiation of targeted nanodrug delivery in vivo by a multifunctional magnetic implant. ACS Appl. Mater. Interfaces 2017, 9, 20771-20778. [CrossRef] [PubMed]

271. Saatchi, K.; Tod, S.E.; Leung, D.; Nicholson, K.E.; Andreu, I.; Buchwalder, C.; Schmitt, V.; Häfeli, U.O.; Gray, S.L. Characterization of alendronic- and undecylenic acid coated magnetic nanoparticles for the targeted delivery of rosiglitazone to subcutaneous adipose tissue. Nanomed. Nanotechnol. Biol. Med. 2017, 13, 559-568. [CrossRef] [PubMed]

272. Wei, H.; Bruns, O.T.; Kaul, M.G.; Hansen, E.C.; Barch, M.; Wisniowska, A.E.; Chen, O.; Chen, Y.; Li, N.; Okada, S.; et al. Exceedingly small iron oxide nanoparticles as positive MRI contrast agents. Proc. Natl. Acad. Sci. USA 2017, 114, 2325-2330. [CrossRef] [PubMed]

273. Toth, G.B.; Varallyay, C.G.; Horvath, A.; Bashir, M.R.; Choyke, P.L.; Daldrup-Link, H.E.; Dosa, E.; Finn, J.P.; Gahramanov, S.; Harisinghani, M.; et al. Current and potential imaging applications of ferumoxytol for magnetic resonance imaging. Kidney Int. 2017, 92, 47-66. [CrossRef]

274. Ulbrich, K.; Holá, K.; Šubr, V.; Bakandritsos, A.; Tuček, J.; Zbořil, R. Targeted Drug Delivery with Polymers and Magnetic Nanoparticles: Covalent and Noncovalent Approaches, Release Control, and Clinical Studies. Chem. Rev. 2016, 116, 5338-5431. [CrossRef]

275. Min, Y.; Caster, J.M.; Eblan, M.J.; Wang, A.Z. Clinical Translation of Nanomedicine. Chem. Rev. 2015, 115, 11147-11190. [CrossRef]

276. Rosenblum, D.; Joshi, N.; Tao, W.; Karp, J.M.; Peer, D. Progress and challenges towards targeted delivery of cancer therapeutics. Nat. Commun. 2018, 9, 1-12. [CrossRef]

277. Prügger, F.; Mallner, B.; Schlipköter, H.W. [Polyvinylpyridine N-oxide (Bay 3504, P-204, PVNO) in the treatment of human silicosis]. Wien. Klin. Wochenschr. 1984, 96, 848-853.

278. Garbuio, D.C.; Zamarioli, C.M.; De Melo, M.O.; Campos, P.M.B.G.M.; De Carvalho, E.C.; De Freitas, L.A.P. Safety of a formulation containing chitosan microparticles with chamomile: Blind controlled clinical trial. Rev. Lat. Am. Enferm. 2018, 26 , e3075. [CrossRef]

279. Shao, Y.; Zhou, H. Clinical evaluation of an oral mucoadhesive film containing chitosan for the treatment of recurrent aphthous stomatitis: A randomized, double-blind study. J. Dermatol. Treat. 2019, 31, 1-5. [CrossRef] [PubMed]

280. Shaw, G.; Lee-Barthel, A.; Ross, M.L.; Wang, B.; Baar, K. Vitamin C-enriched gelatin supplementation before intermittent activity augments collagen synthesis. Am. J. Clin. Nutr. 2016, 105, 136-143. [CrossRef]

281. Lamo-Espinosa, J.M.; Mora, G.; Blanco, J.F.; Granero-Moltó, F.; Núñez-Córdoba, J.M.; López-Elío, S.; Andreu, E.; Sánchez-Guijo, F.; Aquerreta, J.D.; Bondía, J.M.; et al. Intra-articular injection of two different doses of autologous bone marrow mesenchymal stem cells versus hyaluronic acid in the treatment of knee osteoarthritis: Long-term follow up of a multicenter randomized controlled clinical trial (phase I/II). J. Transl. Med. 2018, 16, 213. [CrossRef] [PubMed] 